\title{
D. Rodrigo e frei Mariano: A política portuguesa de produção de salitre na virada do século XVIII para o XIX
}

\author{
Magnus Roberto de Mello Pereira*
}

\section{RESUMO}

Assim que assumiu a pasta da Marinha e do Ultramar, em 1796, d. Rodrigo de Souza Coutinho desencadeou um processo que buscava resolver a dependência portuguesa da importação de salitre. Reuniu à sua volta uma equipe composta em sua maioria por luso-brasileiros. João da Silva Feijó, frei Mariano da Conceição Veloso e Manuel Jacinto Nogueira da Gama foram incumbidos de fazer experiências sobre a produção artificial de salitre. Simultaneamente, a mando do ministro, Veloso iniciou o processo de traduçáo e publicação de obras francesas e inglesas sobre o assunto. Tanto o empreendimento editorial do Arco do Cego quanto a produção de salitre, e ainda o envolvimento de luso-brasileiros em ambos, são processos concomitantes e imbicados e fruto de uma política coerente e orientada, a qual é objeto do presente estudo.

Palavras-chave: salitre; Arco do Cego; d. Rodrigo de Souza Coutinho; Mariano da Conceição Veloso.

\section{ABSTRACT}

As soon as d. Rodrigo de Souza Coutinho took over as the Navy and Overseas Ministry, in 1796, he started a process that would try to solve the Portuguese dependency of imported saltpeter. He gathered around him a team comprised mostly of Portuguese-Brazilians. João da Silva Feijó, fray Mariano da Conceição Veloso and Manuel Jacinto Nogueira da Gama received orders to do experiments on the artificial production of saltpeter. Simultaneously, at the minister's behest, Veloso started the translation and publication of French and English books on the subject. The publishing company Arco do Cego and the production of saltpeter, besides the involvement of Luso-Brazilians in both initiatives, are concurrent and 


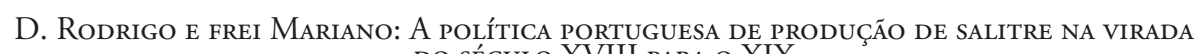
DO SÉCULO XVIII PARA O XIX

Magnus Roberto de Mello Pereira

intertwined processes, resulting from a coherent and focused policy, which is the object of this study.

Keywords: saltpeter, Arco do Cego, Rodrigo de Souza Coutinho, Mariano da Conceição Veloso.

Figura de longa vida política, Martinho de Melo e Castro foi ministro de d. José, ministro continuou com d. Maria e ministro permaneceu na regência de d. João. Quando morreu, em 1796, para sucedê-lo na pasta da Marinha e Ultramar foi chamado d. Rodrigo de Souza Coutinho. O novo ministro integrava o grupo de famílias que dominava a administração ultramarina portuguesa, as quais, pela experiência adquirida em sucessivos cargos, garantiam a governabilidade do império português. Essas famílias integravam redes clientelares caracterizadas por "cadeias de nomeaçóes de diversos oficiais régios (...) intermediadas pelo fato de que uma dada nomeaçáo abria espaço para a ocorrência de outras nomeaçóes influenciadas pela primeira". ${ }^{1}$ D. Francisco Inocêncio de Souza Coutinho, pai de d. Rodrigo e figura próxima a Pombal, foi governador de Angola e, mais tarde, embaixador plenipotencionário de Portugal na corte espanhola, onde se destacou como um dos artífices do tratado de fronteiras de 1777. Dentro desta lógica de redes clientelares, garantiu a seus filhos cargos importantes na administração portuguesa, mesmo durante o reinado de d. Maria, período nem sempre favorável aos herdeiros do pombalismo.

D. Rodrigo, além de ser afilhado de batismo de Sebastiáo José de Carvalho e Melo, era cria direta dos projetos pedagógicos pombalinos. Seu pai o fez estudar no Colégio dos Nobres, enquanto a maioria da nobreza portuguesa rejeitara a iniciativa. Cursou direito em Coimbra, no exato momento em que as reformas pombalinas de 1772 eram implantadas na velha universidade. Os novos estatutos da Universidade de Coimbra obrigavam a que todos os estudantes, ainda que de cânones ou leis, cursassem as recém-criadas disciplinas de ciências naturais, ${ }^{2}$ o que ajuda a explicar a forte crença na ciência que acompanhou toda a atuação de Souza Coutinho como homem de estado. Neste período, teve como colegas muitos dos luso-brasileiros que, mais tarde, seriam incluídos em seus projetos científicos. Recém-formado em direito, foi nomeado embaixador na corte de Turim e ali permaneceu até ser chamado para a nova missão. ${ }^{3}$

${ }^{1}$ GOUVÊA, Maria de Fátima S. Trajetórias administrativas e redes governativas no Império Português. (1668-1698) In: VIa Jornada Setecentista; Conferências \& Comunicaçóes. Curitiba: Aos Quatro Ventos, 2006. p. 402.

${ }^{2}$ Sobre a reforma da Universidade de Coimbra, ver PEREIRA, Magnus Roberto de Mello; CRUZ, Ana Lúcia Rocha Barbalho da. Ciência e memória: aspectos da reforma da Universidade de Coimbra de 1772. Revista de História Regional, v. 14, p. 7-48, 2009.

${ }^{3}$ Apesar de sua importância, d. Rodrigo era um personagem relativamente pouco estudado. Há pouco tempo, somente, a sua biografia foi alvo de um estudo mais extenso. SILVA, Andrée Mansuy-Diniz. Portrait 
D. Rodrigo e frei Mariano: A política portuguesa de produçấo de salitre na virada DO SÉCULO XVIII PARA O XIX

Magnus Roberto de Mello Pereira

A historiografia corrente nos acostumou a ver no ministro ora um paladino do Brasil, ora o formulador de uma nova política de exploração colonial. No entanto, as suas políticas não eram exatamente "coloniais". Eram projetos de âmbito geral, que incluíam tanto os territórios ultramarinos da coroa portuguesa, quanto os metropolitanos. Souza Coutinho tinha altas pretensóes e tentou utilizar a sua presença no ministério responsável pelas colônias para alavancar, com sucesso, um projeto muito mais amplo de poder, que tinha o propósito claro de dar continuidade a um conjunto de reformas ilustradas já em andamento e garantir a integridade do império português.

Quando ocupou a pasta da Marinha e do Ultramar, uma das principais preocupaçóes da coroa, e consequentemente, de d. Rodrigo, era resolver a dependência portuguesa da importaçáo de potassa e de salitre, problema que comportava uma vertente científica. A potassa era a "matéria-prima essencial para, além do vidro e do sabão, o branqueamento de tecidos, de papel, do açúcar, e no preparo de medicamentos e tinturas". Já o salitre era o principal insumo para a produção da pólvora. Em decorrência, na complexa conjuntura bélica do período, a autossuficiência na produçáo de pólvora de boa qualidade era considerada essencial à manutenção da soberania nacional portuguesa na Europa e nas colônias. Oliveira Lima, autor nem sempre simpático a d. Rodrigo, já afirmava que para ele "a integridade nacional era mais que uma preocupação, constituía uma obsessão.". As medidas que buscavam levar à autossuficiência na produção desses compostos funcionaram como uma espécie de estopim, que pôs em marcha uma sequência de açôes inextricáveis umas das outras, entre elas a constituição da rede de intelectuais luso-brasileiros que passou a gravitar ao redor do ministro. Quando desencadeou o processo, Souza Coutinho acabara de ser nomeado ministro da pasta da Marinha e do Ultramar. O seu campo de ação passava, portanto, obrigatoriamente pelas colônias. Assim, nada mais "natural" do que a aproximação com os muito luso-brasileiros que haviam estudado em Coimbra e permaneceram na metrópole. Aliás, o viés científico de suas políticas levava-o, quase que obrigatoriamente, a essa aproximaçáo.

Sem desconsiderar o decisivo papel econômico que, à época, a coroa atribuía às capitanias brasileiras, é preciso levar em conta outros dois aspectos. A independência de algumas colônias inglesas da América do Norte acendera um claro sinal de perigo. A elite colonial brasileira, até pela própria formação na Universidade de Coimbra reformada por Pombal, facilmente poderia ser contagiada por esse exemplo. O caso da conjura mineira e o quase perdão dado aos revoltosos são um forte indício de que a coroa náo buscava o confronto, mas uma acomodação. $\mathrm{O}$ que se seguiu foi uma tentativa de fazer de conta que nada acon-

d'un homme d'État: D. Rodrigo de Souza Coutinho, Comte de Linhares, 1755-1812. Paris: Centre Culturel Calouste Gulbenkian, 2006.

${ }^{4}$ LUNA, Fernando J. Alographia dos álkalis... de Frei Conceição Veloso: um manual de química industrial para produção da potassa no Brasil colonial. Química Nova, v. 31, n.8, p. 2214, 2008.

${ }_{5}^{5}$ OLIVEIRA LIMA, Manuel de. D. João VI no Brasil. Rio de Janeiro: Typ. do Jornal do Commercio, 1908. p. 234. 
D. Rodrigo e frei Mariano: A política portuguesa de produção de salitre na virada DO SÉCULO XVIII PARA O XIX

Magnus Roberto de Mello Pereira

tecera. Com d. Rodrigo, este deliberado ignorar transformou-se em política de cooptação e ele não hesitou em trazer para a sua órbita suspeitos e condenados de participaçáo na inconfidência. O outro aspecto a considerar é que a mão de obra científica disponível em Portugal naquele período era quase toda composta de luso-brasileiros egressos da Universidade de Coimbra. Entre os metropolitanos, foi baixo o interesse despertado pelas novas carreiras científicas criadas com a reforma da Universidade. Os motivos que teriam levado a tal rejeição não são plenamente conhecidos. Mas, de fato, qualquer "família" portuguesa sabia que o binômio padre-advogado garantia posição e estabilidade econômica a seus rebentos. Já os portugueses da América acreditaram no aceno feito pela coroa de que os melhores alunos das novas carreiras científicas seriam agraciados com comissôes e empregos públicos. Alguns mais precavidos, como o mineiro Vicente Jorge Dias Cabral, um dos muitos mobilizados por Souza Coutinho, apostaram na dupla formação: "Sempre ansioso de empregar-me no serviço de S. Majestade segui a Carreira das Letras indo estudar à Universidade de Coimbra; e ali me apliquei à Filosofia fazendo Formatura nesta Ciência, como tão bem no Direito Civil, querendo facilitar o emprego, já pelo meio das Ciências Naturais, já pelas positivas". ${ }^{6}$

Assim, quer pela pasta que ocupava, quer como política intencional de cooptação, quer pela disponibilidade de quadros científicos nascidos no Brasil, quer ainda pelo convívio na Universidade, foi quase 'natural' a aproximaçấo entre o novo ministro - estrangeirado, afilhado de Pombal e cultor das ciências - e a elite intelectual proveniente das colônias americanas, que rezava pelo mesmo catecismo. Essa parceria teve início assim que Souza Coutinho assumiu a pasta, mas não limitou-se aos que estudaram em Coimbra. $\mathrm{O}$ frade franciscano Mariano da Conceição Veloso, que não passara pela Universidade, foi um dos primeiros colonos ilustrados a integrar a rede criada pelo ministro.

Veloso, como é sabido, fizera um amplo levantamento da flora do Rio de Janeiro, por ordem de d. Luís de Vasconcelos. Quando o vice-rei retornou a Lisboa, o naturalista o acompanhou, com o propósito de publicar a sua Flora Fluminensis. A iniciativa da aproximaçáo com Souza Coutinho partiu do frade, que, desgostoso com o impasse da publicação da obra, enviou-lhe uma carta cheia de queixumes, "pelo mesmo módo que um filho que se queixa a hum Pai". A carta permite perceber a complexa forma discursiva através da qual um luso-brasileiro do período construía o seu sentido de pertença à nação imperial portuguesa. ${ }^{7}$

Sim, Ex ${ }^{\text {mo }}$ Sr., V. Ex cia é o Órgão do Pai comum desta Nação, que se acha repartida, pelas três partes, que inteiram o Globo do Mundo, fora em a que estamos. Esta, certamente, é a

\footnotetext{
${ }^{6}$ AHU, Maranhão, Cx.127, D9555.

7 Sobre a questão da identidade dos cientistas luso-brasileiros, ver PEREIRA, Magnus Roberto de Mello; CRUZ, Ana Lúcia Rocha Barbalho da. Ciência, identidade e quotidiano: alguns aspectos da presença de estudantes brasileiros na Universidade de Coimbra, na conjuntura final do período colonial. Revista de História da Sociedade e da Cultura, Coimbra, v. 9, p. 205-228, 2009.
} 
D. Rodrigo e frei Mariano: A política portuguesa de produçấo de salitre na virada DO SÉCULO XVIII PARA O XIX

Magnus Roberto de Mello Pereira

qualidade, com que V. Ex ${ }^{\text {cia }}$ acolhe na sua presença, os emigrados filhos da Mãe Comum, que nos Países estranhos sustentam a sua glória. ${ }^{8}$

Inicialmente, a correspondência detém-se na descrição da produção científica do frade. Eram "onze volumes em fólio, com dois de Descrições", "uma Coleção de todos os peixes de água doce, e salgada”, "outra de Insetos marinhos, e terrestres” e, finalmente, a joia de sua coleção, um livro de "Borboletas Impressas, pela fécula colorante de que se cobrem".

Essa carta traz também alguns aspectos pouco explorados da biografia de Mariano da Conceição Veloso. Como ele próprio diz, não chegou a exercer a função de professor em São Paulo, como insistem seus biógrafos. Foi ali, no entanto, que no final da década de 1770 iniciou as suas atividades de coletor de produtos de História Natural.

Que sendo mandado pela obediência para o Convento da Cidade de S. Paulo; por Petição do Il ${ }^{\mathrm{mo}}$ D. Luís Antônio de Souza, então seu General, para ensinar Geometria aos Soldados, que não se verificou; fui empregado pelo seu Sucessor o Ill ${ }^{\text {mo }}$ Martim Lobo de Saldanha, no último triênio do seu Governo, em recolher as produções naturais do País mais preciosas, para serem remettidas ao Museu, e Jardim de Sua Majestade, por uma ordem que teve primeiramente, em o ano de 1777 do Ex ${ }^{\text {mo }}$ Marquês de Pombal, repetida ao depois pelo Ill $^{\text {mo }}$, e Ex ${ }^{\text {mo }}$ Martinho de Mello, o que o suplicante satisfez de sorte.

Que sendo informado disto pelo Il $^{\mathrm{mo}}$ e Ex ${ }^{\mathrm{mo}}$ Luiz de Vaconcellos, então Vice-Rei do Rio de Janeiro, o mandou vir, por ordem do seu prelado, para esta Cidade, para onde veio, em companhia do mesmo General, o Il $^{\text {mo }}$ Martim Lopes, no ano de 1780; e se apresentou a S. Ex ${ }^{\text {a }}$ o Ill ${ }^{\text {mo }}$ e $\mathrm{Ex}^{\text {mo }}$ Sr. Vice-Rei, que fez cair sobre os ombros do Suplicante todo o peso do exame, e Coleção das produçóes naturais desta capitania, por mais que Suplicante lhe representasse a debilidade das suas forças para este emprego. ${ }^{10}$

Só depois de se referir à sua atuação em São Paulo frei Mariano passa a narrar o processo de recolha da flora fluminense e a sua ida para Lisboa, aspectos biográficos amplamente explorados pela historiografia, os quais não precisam ser reiterados.

No conjunto, esta carta é preciosa, pois além das informações únicas de seu conteúdo ela foi vazada em um formato muito característico do Antigo Regime. Inicia com uma série de fórmulas de submissão vassalática, estende-se por uma longa folha corrida de serviços prestados à coroa, para então solicitar uma mercê régia, no caso o apoio à impressão da Flora Fluminensis. A historiografia contemporânea tem utilizado, com grande proveito, categorias como dom, dádiva ou mercê para explicar alguns mecanismos internos do funcionamento

\footnotetext{
${ }^{8}$ AHU, Reino, maço 2719.

${ }^{9}$ Este códice ainda existe e integra o acervo de obras raras do Museu Bocage, em Lisboa.

${ }^{10}$ AHU, Reino, maço 2719.
} 
D. Rodrigo e frei Mariano: A política portuguesa de produçấo de salitre na virada DO SÉCULO XVIII PARA O XIX

Magnus Roberto de Mello Pereira

do Antigo Regime europeu. Pedir, conceder ou receber mercês não eram açôes isoladas ou distorçôes, mas atos que se inseriam em cadeias de obrigaçôes recíprocas inerentes ao próprio funcionamento daquelas sociedades. ${ }^{11}$ Essas formas de agir, como as adotadas por Veloso, eram funcionais, pois elas se enquadravam perfeitamente na cultura política portuguesa da época. O projeto "fomentista" iniciado por Pombal e continuado por Souza Coutinho baseava-se em duas perspectivas políticas, que hoje parecem paradoxais, mas que à época eram perfeitamente compatíveis e operacionais. Como advertiu o historiador Ramada Curto: "A oposiçáo entre uma maneira de conceber a política fundada na reforma do aparelho de Estado, no domínio fiscal, militar ou da administração da justiça, e uma outra, baseada em dádivas liberais, mercês e na formação de laços pessoais ou clientelares tinha as suas raízes bem localizadas numa cultura política de Antigo Regime". ${ }^{12}$

Precisamente a 10 de agosto de 1797, frei Mariano passou a trabalhar diretamente com o ministro. ${ }^{13} \mathrm{O}$ que se processou naquele exato momento foi a transferência de Veloso da rede clientelar do ex-vice-rei d. Luís de Vasconcelos, para a de d. Rodrigo de Souza Coutinho. Nesta época, o frade teria inclusive mudado da casa do primeiro, onde morava desde que viera para Lisboa, para a do segundo. O ministro chegou a dar ordens expressas para que fossem concedidos diversos apoios e facilidades para a publicaçáo da Flora Fluminensis, sem grandes resultados. ${ }^{14}$ Veloso parece ter encontrado no abade Correia da Serra, secretário da Academia das Ciências, um opositor de peso à impressão da sua Flora. ${ }^{15}$ Os historiadores Nunes e Brigola já explicaram os múltiplos obstáculos, de ordem científica, inclusive, que levaram ao abandono dessa empreitada. ${ }^{16}$

O que se observa entáo é o estabelecimento de uma parceria entre o naturalista e o ministro, com vistas a enfrentar a questão do salitre, tópico de primeira ordem nas preocupaçôes de d. Rodrigo. A partir deste ponto percebe-se a progressiva imersão de Veloso na agenda do ministro. No entanto, essa parceria, que iria desembocar no empreendimento editorial do Arco do Cego, ainda é mal compreendida pela historiografia.

Os temas da Oficina Calcográfica do Arco do Cego e da produção do salitre no Brasil colônia vêm sendo abordados por historiadores do Brasil e de Portugal desde o século XIX. No passado, contudo, tais temáticas raramente foram tratadas autonomamente. Apareciam,

\footnotetext{
${ }^{11}$ PEREIRA, Magnus Roberto de Mello. Rede de mercês e carreira: o "desterro d'Angola” de um militar luso-brasileiro (1782-1789). História: Questóes e Debates, v. 45, p. 111, 2008.

${ }^{12}$ CURTO, Diogo Ramada. D. Rodrigo de Sousa Coutinho e a Casa Literária do Arco do Cego. In: A Casa Literária do Arco do Cego (1799-1801). Lisboa: Imprensa Nacional/Casa da Moeda, 1999. p. 32.

${ }^{13}$ AHU, Reino, maço 23.

${ }^{14}$ BORGMEIER, Tomaz, O.F.M. Flora Fuminensis de Frei José Mariano da Conceição Vellozo. Documentos. Rio de Janeiro: Arquivo Nacional, 1961. p. 21.

${ }^{15}$ AHU, Reino, maço 2719.

${ }^{16}$ NUNES, Maria de Fátima; BRIGOLA, João Carlos. José Mariano da Conceição Veloso (1742-1811), um frade no Universo da Natureza. In: A Casa Literária do Arco do Cego (1799-1801). Lisboa: Imprensa Nacional / Casa da Moeda, 1999. p. 60-62. In: CURTO, Diogo Ramada et. al.
} 
D. Rodrigo e frei Mariano: A política portuguesa de produção de salitre na virada DO SÉCULO XVIII PARA O XIX

Magnus Roberto de Mello Pereira

de forma derivada, em textos laudatórios a um ou outro personagem, como José Mariano da Conceição Veloso, Antônio Vieira Couto etc. O resultado dessas abordagens foi o desenvolvimento de um quadro feito de fragmentos que não se articulavam: Veloso traduziu e publicou, Feijó tentou produzir salitre, Vieira Couto escreveu sobre etc. Seja porque certos princípios historiográficos nacionalistas adotados à época assim o exigiam, ou simplesmente por desconhecimento dos autores, quase sempre era passada a noção de que se tratavam de iniciativas individuais dos homenageados. Deste modo, permaneceu no obscurecimento o quadro coerente em que as políticas editorias e de transformação produtiva foram concebidas e fomentadas pela coroa portuguesa, diga-se d. Rodrigo, no caso. Somente a partir dos finais da década de 1960 tal quadro começaria a ganhar contornos mais nítidos, graças às contribuiçôes de Maria Odila da Siva Dias, Carlos Guilherme Mota, Fernando Novais e Arno Wehling, entre outros historiadores brasileiros. ${ }^{17}$

Na última década, ambos os temas foram revisitados com frequência e passaram por um processo de renovação historiográfica. Em Portugal, Diogo Ramada Curto, Miguel Faria, Maria de Fátima Nunes e João Carlos Brigola foram os principais autores a tomar os livros produzidos no Arco do Cego como objeto de seus estudos. ${ }^{18}$ No Brasil, o tema recebeu o aporte de Lígia Cunha, Lorelai Kury, Robert Wegner e Caio Boschi, que buscaram entender tais obras em sua condição mais geral de empreendimento colonial português. ${ }^{19}$ Já a história da produção do salitre ainda permanece presa, em sua maior parte, a recortes regionais ou à biografia de alguns intelectuais luso-brasileiros do período colonial. No entanto, ainda que tenham trabalhado com esse tipo de recorte, os pesquisadores envolvidos com o tema procuraram enquadrar os seus objetos de estudo na conjuntura mais ampla das políticas coloniais portuguesas. Assim, a historiografia sobre o salitre também passou por um processo

${ }^{17}$ DIAS, Maria Odila da Silva. Aspectos da ilustraçáo no Brasil. Revista do Instituto Histórico Geográfico Brasileiro, Rio de Janeiro, v. 278, p. 105-170, 1968; MOTA, Carlos Guilherme. Atitudes de inovação no Brasil. 1789-1801. Lisboa: Livros Horizonte, 1972; NOVAES, Fernando. A Estrutura e dinâmica do antigo sistema colonial (séculos XVI-XVIII). São Paulo: Cebrap, 1974; WEHLING, Arno. O fomentismo português no século XVIII: doutrinas, mecanismos, exemplificaçóes. Revista do Instituto Histórico Geográfico Brasileiro, Rio de Janeiro, , v. 316, p. 170-278, 1978.

${ }^{18}$ CURTO, Diogo, op. cit.; FARIA, Miguel Figueira de (Ed.). Casa Literária do Arco do Cego: exemplo singular na história da ediçấo ilustrada em Portugal. Apontamentos para uma biografia. In: Actas do Colóquio "A Casa Literária do Arco do Cego". Anais. Universidade Autónoma de Lisboa, Série História, v. 7-8, 2000 2001; NUNES, Maria de Fátima; BRIGOLA, João Carlos, op. cit.

${ }^{19}$ CUNHA, Lygia da F. F. Notícia Histórica. In: Oficina Tipográfica, Calcográfica e Literária do Arco do Cego. Estampas. Rio de Janeiro: Biblioteca Nacional, 1976; KURY, Lorelai. Homens de ciência no Brasil: impérios coloniais e circulação de informaçóes (1780-1810). História, Ciências, Saúde: Manguinhos, v. 11, supl. 1, p. 109-129, 2004; WEGNER, Robert. Livros do Arco do Cego no Brasil colonial. História, Ciências, Saúde: Manguinhos, v. 11, supl. 1, p. 131-140, 2004; BOSCHI, Caio. Política e edição: Os naturais de Brasil nas reformistas oficinas do Arco do Cego. In: DUTRA, Eliana; R. MOLLIER, Jean-Yves. (Orgs.). Política, nação e edição: o lugar dos impressos na construção da vida política: Brasil, Europa e Américas nos séculos XVIII-XX. São Paulo: Annablume, 2006. p. 495-510. 
D. Rodrigo e frei Mariano: A política portuguesa de produção de salitre na virada DO SÉCULO XVIII PARA O XIX

Magnus Roberto de Mello Pereira

de renovação, conduzida por autores como Márcia Ferraz, Silvia Figuerôa, Margarete Lopes, Clarete Silva, Ermelina Pataca, Alex Varela, Fernando Luna, entre outros. ${ }^{20}$

Apesar de toda esta renovação, a historiografia continua a ser oscilante quanto aos papéis de cada um na parceria entre d. Rodrigo e frei Mariano. Mesmo autores portugueses como Nunes e Brigola, responsáveis por um cuidadoso e indispensável texto sobre a trajetória do naturalista, cairam em algumas armadilhas que lhes foram impostas pela tradição historiográfica brasileira. Esses autores dão-se conta de que, no século XIX, houve uma operação destinada a construir um panteão científico nacional, que teve por quartel-general o IHGB. Percebem muito bem que, em torno de Conceição Veloso, foi construída uma "história entretecida de silêncios, de penumbras factuais e de exaltaçóes interpretativas, propícias à elaboração do 'mito heróico' do infeliz frade, injustiçado em vida, mas recuperada e 'vingada' a sua imagem científica em tempos oitocentistas de contrução de nova Nação brasileira". ${ }^{21}$ No entanto, em outros momentos, os autores devolvem o protagonismo a Veloso. De fato, o naturalista teria feito "publicar em Lisboa o periódico agrário Paladio Portuguez e Clarim de Palas". No entanto, parece um tanto exagerada a afirmação de que, a partir de 1796, "encontramos o frade envolvido no esforço de criar uma rede de tipografias disponíveis para, a exemplo das 'naçốes cultas e civilizadas', dar conhecimento da 'Nova Agricultura' baseada nos princípio agronômicos decorrentes da filosofia natural setecentista”. Ou seja, há momentos em que, na atual historiografia, a questáo continua a ser tratada de maneira semelhante à abordagem personalista utilizada pelos historiadores do século XIX: Veloso traduziu, Veloso publicou, Veloso tinha planos. Ou, seja, muitos dos autores contemporâneos insistem em imaginar que o frade-naturalista atuava segundo seus próprios desígnios. Outros ainda continuam atribuindo ao franciscano o papel preponderante na criação e na orientação editorial do empreendimento do Arco do Cego. Que Veloso tornou-se uma figura poderosa no meio intelectual português do período, não há dúvidas. Contudo, há que lembrar sempre que ele era detentor de um poder derivado. Mesmo na área da difusão de conhecimento sobre plantas consideradas úteis à economia, que costumamos vincular à esfera de interesse do religioso, era a d. Rodrigo que muitas vezes cabiam as "sugestôes" sobre o que publicar. Indícios disso podem ser observados nos despachos do ministro. Em outubro de 1798, por

\footnotetext{
${ }^{20}$ FERRAZ, Márcia H. M. A produçáo do salitre no Brasil colonial. Química Nova, v. 23, p. 845-850, 2000; FIGUEIRÔA, Silva F. de M.; SILVA, Clarete P. da; PATACA, Ermelinda M. Aspectos mineralógicos das "Viagens Filosóficas" pelo território brasileiro na transição do século XVIII para o século XIX. História, Ciências, Saúde: Manguinhos, v. 11, p. 713-729, 2004; LOPES, Maria Margaret; SILVA, Clarete Paranhos; FIGUEIRÔA, Sílvia F. de M.; PINHEIRO, Rachel. Scientific culture and mineralogical sciences in the Luzo-Brazilian Empire-the work of João da Silva Feijó (1760-1824) in Ceará. Science in Context, v. 18, p. 201-224, 2005; VARELA, Alex G. Juro-lhe pela honra de bom vassalo e bom português: análise das memórias científicas de José Bonifácio de Andrada e Silva (1780-1819). São Paulo: Annablume, 2006; LUNA, Fernando J. Frei José Mariano da Conceição Veloso e a divulgação de técnicas industriais no Brasil colonial: discussão de alguns conceitos das ciências químicas. História, Ciências, Saúde: Manguinhos. Rio de Janeiro, v. 16 , p. $145-155,2009$.

${ }^{21}$ NUNES, Maria de Fátima; BRIGOLA, João Carlos, op. cit. p. 71.
} 
D. Rodrigo e frei Mariano: A política portuguesa de produção de salitre na virada DO SÉCULO XVIII PARA O XIX

Magnus Roberto de Mello Pereira

exemplo, ele ordenou ao secretário João Filipe da Fonseca que "com Carta de recado remeta amanhã ao Padre Veloso essas descriçóes da caneleira, da pimenteira, e de uma Máquina chinesa para cardar algodáo para que ele veja se contém coisa que mereça ser publicada". ${ }^{22}$

A ação do ministro nesta área ultrapassava, inclusive, o âmbito do Arco do Cego. Era comum também que indicasse textos a publicar na imprensa periódica portuguesa. Um pequeno ensaio enviado dos Açores pelo luso-brasileiro Luís Antônio Araújo sobre a cultura da junça (tiririca) foi parar nas páginas do Correio Mercantil por ordem expressa de d. Rodrigo. ${ }^{23}$

Fernando Luna foi um dos primeiros autores a colocar Veloso no lugar que, de fato, the competiu: o de um coadjuvante; poderoso e com méritos, mas coadjuvante. ${ }^{24}$ Para o autor, o condutor do projeto político era d. Rodrigo. Projeto no qual Veloso foi incluído como braço direito editorial, mas não só editorial, como veremos. "Ao entregar a direçâo da recém-criada Tipografia do Arco do Cego a Veloso, d. Rodrigo colocava em prática seu projeto político, que consistia em realçar a importância do Brasil para o vigor do Império". ${ }^{25}$ A pequena ressalva que se pode fazer a essa afirmação é de ordem cronológica. O projeto do ministro e o papel nele desempenhado por Veloso antecediam a instalação da imprensa calcográfica no Arco do Cego. A documentaçáo remanecente do empreendimento mostra que tanto as obras que trazem a imprenta da Casa Literária quanto as publicadas anteriormente em outras casas editoriais eram arroladas indistintamente em diversos "Catálogos dos livros impressos por ordem de Sua Majestade". ${ }^{26}$ Ou seja, elas foram impressas por ordem de d. Rodrigo, atendendo estritamente à agenda política e econômica por ele ditada. ${ }^{27}$ Aliás, essas obras também traziam impressa a chancela régia, o que já lhes conferia caráter oficial e as dispensava de passar por censura prévia. Explorando as dedicatórias dos livros do Arco do Cego, inclusive as dos livros da fase prévia à instalação, é possível perceber que o próprio Souza Coutinho aproveitava o processo editorial para reiterar a sua proximidade com o príncipe regente d. João, a quem as obras eram exclusivamente dedicadas e a quem era atribuída a condição de coautor da iniciativa da edição. ${ }^{28}$

\footnotetext{
${ }^{22}$ AHU, Reino, maço 158A.

${ }^{23}$ O despacho ordenando a publicação, datado de 6 de novembro de 1800, está em AHU, Açores, Caixa 37, doc. 13. A ordem do ministro foi rapidamente cumprida e no mês seguinte o artigo apareceu no periódico. Ver Correio Mercantil e Economico de Portugal, n. 52, 30 dez. 1800.

${ }^{24}$ Outro trabalho recente que aponta na mesma direção é BRAGANÇA, Aníbal. Arco do Cego e Impressão Régia (Lisboa e Rio de Janeiro): sobre rupturas e continuidades na implantação da imprensa no Brasil. In: XXXI CONGRESSO BRASILEIRO DE CIÊNCIAS DA COMUNICAÇÃO, Natal, 2008.

${ }^{25}$ LUNA, Fernando, 2009, op. cit., p. 157.

${ }^{26}$ AHU, Reino, maço 30A. Negritos meus.

${ }^{27}$ Embora haja a suspeita, como informou o historiador Luiz Carlos Villalta, de que, por vezes, Mariano Veloso extrapolava os poderes que lhe eram confiados, editando obras sem o conhecimento do ministro. VILLALTA, Luiz Carlos. Impressão em Portugal: da política régia às publicaçôes ilegais. (c. 1750-1806). Disponível em: <http://s3.amazonaws.com/academia.edu.documents/30978426/Villalta_PoliticaEditorialRegiaeImplegalem2011.pdf?AWSAccessKeyId=AKIAIR6FSIMDFXPEERSA\&Expires=1380558714\&Signature=IdivaZ1bv mmwO5c646YLGqD6JX0\%3D\&response-content-disposition=inline>. Acesso em: 30 set. 2013.

${ }^{28}$ Ver DENIPOTI, Cláudio; PEREIRA, Magnus Roberto de Mello. Sobre livros e dedicatórias: D. João e a
} 
D. Rodrigo e frei Mariano: A política portuguesa de produçấo de salitre na virada DO SÉCULO XVIII PARA O XIX

Magnus Roberto de Mello Pereira

Os livros eram, contudo, apenas uma parcela do processo utilizado por $\mathrm{d}$. Rodrigo para reforçar os laços com o Príncipe Regente. Muitos autores insistem no caráter predominantemente religioso da educação do príncipe d. João. No entanto, ela também tivera um viés ilustrado, pois figuras importantes do ambiente intelectual português da época, como Antônio Domingues do Paço, o naturalista Manuel do Cenáculo e o matemático Miguel Franzini, haviam participado de sua formação. Assim, o príncipe também demonstrava gosto pelas coisas da ciência e Souza Coutinho valia-se disto para atraí-lo para seus projetos, inclusive o da produção de salitre.

O Il ${ }^{\mathrm{mo}}$ e Ex ${ }^{\mathrm{mo}}$ Senhor D. Rodrigo de Sousa Coutinho manda participar ao Senhor D ${ }^{\mathrm{r}}$. Alexandre Rodrigues Ferreira que Sua Alteza Real o Príncipe Nosso Senhor tem determinado, ir sábado ao Museu, para ver o salitre, Canela, e mais Produtos, que vieram agora no Comboio da América = Secretaria de Estado em 11 de Julho de $1799=$ PS = O mesmo Ex ${ }^{\text {mo }}$ Senhor Ordena, que Sua Mercê tenha no referido dia no Museu uma pouca de Pólvora da melhor, para se experimentar, e comparar com uma Amostra, que veio do Brasil, para que se lhe há de remeter do Arsenal Real da Marinha um Provador, na conformidade do que se ordenou ao Inspetor do mesmo Arsenal. ${ }^{29}$

Da mesma forma, frei Veloso buscava aproximar-se de d. João e obter benesses, exibindo os seus dotes de naturalista. Solicitou a d. Rodrigo que mostrasse ao príncipe o seu precioso livro de borboletas, tentando obter apoio para imprimi-lo.

Que V. Exa queira fazer ver a S. Alteza um Livro de Borboletas do Brasil impressas com a própria tinta de suas asas, ou fécula colorante das suas membranosas asas, que não há em Museu algum outra obra, que a iguale neste gênero. E ao mesmo tempo a graça de as poder fazer copiar sem detrimento algum do original, para as mandar abrir que estando a imprimir obras alheias, é justo que não esqueça das minhas. ${ }^{30}$

A documentação não conta se Souza Coutinho atendeu ao pedido de frei Mariano. O que se sabe é que o livro das borboletas do Brasil continua inédito.

\section{Sobre livros e salitre}

Um frequente equívoco na abordagem dos temas em questão é subestimar as preocupaçốes do ministro com o problema do salitre. De fato, a busca por autossuficiência na pro-

Casa Literária do Arco do Cego (1799-1801). História Unisinos, v. 17, p. 257-271, 2013.

${ }^{29}$ AHMCUL, Cód.1863.

${ }^{30}$ AHU, Reino, 158A. "Abrir" é o termo empregado para referir-se ao trabalho dos gravadores com instrumentos de corte nas chapas de impressão. 
D. Rodrigo e frei Mariano: A política portuguesa de produÇão de Salitre na virada DO SÉCULO XVIII PARA O XIX

Magnus Roberto de Mello Pereira

dução deste composto químico parece anteceder sua atuação editorial. Em outros termos, o salitre teria sido o responsável pelo desencadear do projeto editorial. No mesmo ano em que assumiu a pasta do ultramar, Souza Coutinho enviou cartas-régias ao vice-rei do Brasil e a diversos governadores de capitanias ordenando que fossem feitas indagaçôes sobre a existência de jazidas de salitre economicamente aproveitáveis. As ordens da coroa provocaram toda uma sequência de açóes práticas no terreno, principalmente nas capitanias de Sáo Paulo, Pernambuco, Bahia e Minas Gerais. Adiante voltaremos a elas.

As políticas de $\mathrm{d}$. Rodrigo buscavam resolver alguns gargalos produtivos estratégicos para Portugal, como no caso dos nitratos, ou desenvolver novos ramos econômicos agrícolas e minerais. Todavia, já no começo do século XIX, alguns autores procuraram desqualificar o futuro conde de Linhares justamente por sua insistência em transformar o quadro produtivo e por cercar-se de supostos "bajuladores". Pode-se deduzir que sob o epíteto o autor referia-se também aos muitos luso-brasileiros que, como Conceição Veloso, auxiliavam o ministro.

[Ele] foi um homem bom, cheio de patriotismo, com amplos e variados conhecimentos, inimigo da superstição, mas essas qualidades eram manchadas pela violência de caráter, falta de equilíbrio, a precipitação nas suas resoluçôes, o que o tornou joguete dos muitos bajuladores e fazedores de projetos de que estava cercado e que não lhe permitiam refletir antes de começar e amadurecer seus planos antes de colocá-los em ação. ${ }^{31}$

Aos poucos, a crítica historiográfica à atuação do ministro acabou por tentar transformá-lo numa espécie de criatura irresponsável ou mesmo ridícula. O ponto marcante desse processo foi a anedota, difundida por Oliveira Lima em 1908, de que a rainha Carlota Joaquina se referia a d. Rodrigo como Doutor Trapalhada ou Doutor Barafunda. ${ }^{32}$ Essa blague, não se sabe se fundamentada ou não, ${ }^{33}$ até hoje acompanha o ministro na historiografia mais ligeira sobre o tema da Corte no Brasil. Tais críticas, contudo, costumam esconder uma tradição de pensamento conservador, para a qual as tentativas de transformação eram sempre coisas irrefletidas, ou que não existiriam os requisitos necessários, ou que eram resultados de raciocínios fora de lugar ou de tempo.

Antes de ser um açodado, Souza Coutinho parecia ser pessoa metódica e ciente das dificuldades de introduzir e desenvolver a produção de novos insumos, e de que era preciso enfrentá-las sob múltiplos aspectos. A sua política inaugural, a de resolver o problema de abastecimento de salitre, é uma excelente mostra de seu modus operandi. A produção do

${ }^{31}$ LENORMAND, Marie-Anne. Histoire de Jean VI, roi de Portugal: depuis sa naissance jusqu'a sa mort en 1826, avec des particularités sur sa vie privée et sur les principales circonstances de son règne. Paris: Ponthieu, 1827. p. 18-19.

${ }^{32}$ OLIVEIRA LIMA, Manuel de, op. cit., p. 236.

${ }^{33}$ Sobre a veracidade dessa alcunha, ver MACEDO, Roberto. História administrativa do Brasil. Rio de Janeiro: Dasp, 1964. v. 6, p. 138. 
D. Rodrigo e frei Mariano: A política portuguesa de produção de salitre na Virada DO SÉCULO XVIII PARA O XIX

Magnus Roberto de Mello Pereira

composto, como já mencionado, comportava uma vertente de saber científico. Nada mais natural, portanto, do que cercar-se das pessoas que dominavam o tema, ou que, pelo menos, tivessem uma formação prévia que as habilitasse. Os auxiliares que recrutava estavam longe de serem "fazedores de projetos" que aliciavam o ministro. Eram quase sempre pessoas com formação ou potencial e eram recrutadas por ele ou por seus auxiliares mais diretos. O passo seguinte, cuja lógica é irrepreensível, consistia em reunir a bibliografia europeia diponível sobre o tema. No entanto, não bastava fazer circular essa bibliografia estrangeira entre os integrantes das equipes por ele mobilizadas. Souza Coutinho buscou tornar essas obras assessíveis a um público maior através de um processo sistemático de tradução e publicação. Como homem do iluminismo, d. Rodrigo acreditava no poder da palavra impressa. ${ }^{34} \mathrm{O}$ passo seguinte foi ensaiar a produção em escala experimental, ou sob sua supervisão direta ou atribuindo a tarefa a algum administrador colonial. Em diversos casos, as experiências feitas em pequena escala resultavam em novas publicaçôes que marcavam o ganho tecnológico alcançado, as quais também eram impressas e distribuídas para o público ampliado. $\mathrm{Na}$ sequência, estava previsto que ocorresse a passagem da experimentaçáo para a produçáo em maior escala. Grande parte dos projetos de Souza Coutinho fracassaram justamente nessa última etapa. O que se deduz de tudo isso é que sua "política científica" teve um razoável grau de eficácia, mas as "políticas produtivas" não conseguiram romper os múltiplos obstáculos impostos por questóes muito objetivas, próprias das colônias, e também por interesses e práticas sedimentados. Há que se considerar inclusive que a falta de recursos e a consequente pressa em obter resultados levaram a uma série de problemas de ordem operacional e, provavelmente, ao abandono das propostas de apropriação tecnológica. Esse abandono não invalida o fato de que as açóes de d. Rodrigo ultrapassavam o simples dirigismo de tipo colbertiano, para configurar verdadeiras políticas públicas, pensadas em toda a sua complexidade. António Manuel Hespanha, ao discutir a conformação do estado de polícia (de políticas públicas) em Portugal, aponta para lógica que norteou a escolha dos setores nos quais se fez sentir, desde cedo, a ação dessas políticas.

Os setores de intervenção primordial da "polícia" são aqueles mais diretamente relacionados com o incremento do poder do rei. Desde logo, os setores de interesse estratégico - criação de cavalos, fabrico do salitre e da pólvora, fabrico de armas (metalurgia), fabrico de panos e de cordame (para a marinha), fabrico de biscoitos (para aprovisionar os navios). Depois, e progressivamente, todos os setores que podiam constituir bases importantes de incidência fiscal, nomeadamente a indústria e a agricultura. ${ }^{35}$

\footnotetext{
${ }^{34}$ BOSCHI, Caio, op. cit., p. 498-499.

${ }^{35}$ HESPANHA, António Manuel. Para uma teoria da história institucional do antigo regime. In: Poder e instituiçóes na Europa do antigo regime. Lisboa: Fundação Calouste Gulbenkian, 1984. p. 68. Para efeitos do que nos interessa, o autor apenas esquece de mencionar o setor dos medicamentos, em especial a busca por febrífugos eficazes, como a quina, que garantissem a sobrevivência e adaptação dos europeus aos trópicos.
} 
D. Rodrigo e frei Mariano: A política portuguesa de produçấo de salitre na virada DO SÉCULO XVIII PARA O XIX

Magnus Roberto de Mello Pereira

A documentação disponível, apesar de fragmentária, permite acompanhar o início daquilo que pode ser entendido como o Projeto Salitre do futuro conde de Linhares. Em 1797, o naturalista luso-brasileiro João da Silva Feijó retornou a Lisboa, de volta do arquipélago de Cabo Verde, onde permanecera em missão oficial de exploração científica por cerca de 14 anos. ${ }^{36}$ Feijó e Alexandre Rodrigues Ferreira eram os dois únicos remanescentes em serviço das Viagens Filosóficas, as expediçôes científicas enviadas às colônias em 1783. De certa forma, Veloso também era um remanescente do mesmo processo, com a diferença que sua viagem filosófica fora organizada pelo vice-rei do Brasil e não por Vandelli e pelo ministro Melo e Castro. De volta a Portugal, em 1793, Ferreira retomou suas atividades de naturalista na Ajuda. No ano seguinte, com a morte de Julio Matiazzi, ele foi nomeado administrador e, logo a seguir, vice-diretor do complexo português de história natural. ${ }^{37}$ Quando d. Rodrigo assumiu o Ministério do Ultramar, em 1796, passou a ter Alexandre Rodrigues Ferreira sob seu comando. O ministro já era próximo a Manuel Jacinto Nogueira da Gama, ${ }^{38}$ outro luso-brasileiro dedicado às ciências. Mal desembarcou em Lisboa, João da Silva Feijó foi também acolhido por Souza Coutinho e incumbido de trabalhar com Ferreira no complexo da Ajuda. Formava-se assim o núcleo inicial da rede de homens de ciência luso-brasileiros atuando sob o mando direto do ministro.

Veloso, Feijó e Gama foram a seguir mobilizados nas primeiras tentativas empreendidas com vistas ao domínio das técnicas de produção artificial de salitre. Neste ponto é preciso fazer um parêntesis e frisar mais alguns pontos de discordância com a historiografia corrente sobre os temas em questão. Fora a tentativa mal-sucedida de impressão da Flora Fluminensis, a única proposta editorial própria de Veloso foi a edição do Clarim de Pallas.${ }^{39}$ Chega-se a tal conclusão, ao perceber esta que foi a única obra editada por Veloso que passou pela censura, conforme aparece na portada: "Com licença da Mesa do Desembargo do Paço". ${ }^{40}$ As demais obras que antecederam a instalação da oficina calcográfica já eram resultados da política editorial de d. Rodrigo.

Assim, a atuação editorial de Veloso prévia à parceria com d. Rodrigo era tímida e mal configurava uma proposta editorial própria. Além disto, ele não foi arregimentado pelo ministro especificamente com vistas à criação de uma editora, mas também para o projeto da produção de salitre. Através de instruçôes mandadas pelo ministro a Diogo Inácio de Pina Manique, o temido Intendente de Polícia, sabe-se que Feijó foi incumbido da criação de "Nitreiras artificiais seja das Lamas das ruas de Lisboa seja das Caliças, e Minas, que

${ }^{36}$ PEREIRA, Magnus Roberto de Mello. Um jovem naturalista num ninho de cobras; a trajetória de João da Silva Feijó em Cabo Verde em finais do século XVIII. História: Questôes e Debates, n. 36, p. 29-60, 2002.

${ }^{37}$ AHMCUL, cód. 1863.

${ }^{38} \mathrm{O}$ futuro visconde de Baependi.

${ }^{39}$ VELOSO, Mariano da Conceição (Ed.). Palladio Portuguez e Clarim de Pallas. Lisboa: Officina Patriarcal, 1796. 2 v.

${ }^{40}$ VILLALTA, Luiz Carlos, op. cit., p. 47-48. 
ainda existem em alguns Bairros da cidade", em parceria com frei Veloso. ${ }^{41}$ Feijó organizou os seus experimentos na Ribeira de Alcântara, um bairro portuário de Lisboa, onde ficava a Real Fábrica da Pólvora, e elaborou um pequeno relatório à respeito. Pelo que se depreende deste relato, ele organizou um conjunto de amostras envolvendo exatamente os rejeitos mencionados nas ordens dadas pelo ministro e acompanhou a sua decomposição. Por exemplo, a amostra no 1 era composta de "Estrumes de Gado, e Bestas, e Caliça" a no ${ }^{0}$, de "Lamas das ruas, Estrumes, cascas dos curtumes, cal, caliça". ${ }^{42}$ Veloso, por sua vez, criou uma outra nitreira artificial num lugar emblemático: a Quinta do Arco do Cego. ${ }^{43}$ Tratava-se de uma pequena propriedade rural, situada num barro periférico da capital, utilizada para diversos fins por Pine Manique e por d. Rodrigo. ${ }^{44}$ A seguir, Nogueira da Gama foi incumbido de conduzir um projeto em maior escala, a nitreira do Braço de Prata, comprada a um particular. Enquanto realizava seus experimentos, Mariano da Conceição Veloso, a mando de Souza Coutinho, deu início ao processo de tradução e publicação de obras francesas e inglesas sobre métodos de produzir artificialmente potassa ${ }^{45}$ e salitre, obras que antecedem a instalação da oficina calcográfica no Arco do Cego. Como se percebe, tanto o projeto editorial quanto o de produção de salitre, e ainda o envolvimento de luso-brasileiros em ambos, são coisas concomitantes e imbricadas.

D. Rodrigo deu início à parceria editorial com Veloso com a impressão de uma obra de cunho prático, na qual eram ensinados os métodos de produção artificial de salitre empregados na Virgínia, utilizando os restos da produção de tabaco ${ }^{46} \mathrm{~A}$ seguir foram publicadas uma memória extraída de um manual francês de artilharia ${ }^{47}$ e outra intitulada Memória

\footnotetext{
${ }^{41}$ ANRJ, Negócios de Portugal, Caixa 678.

${ }^{42}$ BNL, cód. 610, f. 10.

${ }^{43}$ GAMA, Manoel Jacinto Nogueira da. Memoria sobre a absoluta necessidade que ha de Nitreiras nacionaes para a independencia e defensa dos Estados: com a descripção da origem, actual estado, e vantagens da Real Nitreira Artificial de Braço de Prata. Lisboa: Impressão Régia, 1803. p. 21.

${ }^{44}$ Alguns autores têm afirmado que a quinta do Arco do Cego era de propriedade privada de Diogo Inácio de Pina Manique. Ver GONÇALVES, Adelto. Bocage: o perfil perdido. Lisboa: Caminho, 2003. p. 271-290. De fato, a quinta do Arco do Cego também era conhecida como a Quinta do Manique. Todavia, no século XVIII existiam mais de uma Quinta do Manique em Lisboa. É provável que essa quinta fosse uma grande propriedade que ia de Santa Apolônia a Arroios, mas que no século XVIII já fora fragmentada em propriedades menores. A Quinta do Manique que seguramente era de propriedade do Intendente ficava em Santa Apolônia, às margens do Tejo, e incluía o baluarte que, ainda hoje, ali existe. No século XIX, seus herdeiros a venderam aos condes de São Vicente (família Távora). Quanto à do Arco do Cego, ainda está por demonstrar se Pina Manique usufruía da quinta como benesse da coroa, ainda que pretendesse ser titular dela, ou se de fato era proprietário da mesma. Ver VILLALTA, Luiz Carlos, op. cit., p. 49-50.

${ }^{45}$ Não vou me deter na questão da potassa, para não fugir do âmbito da proposta, mas a primeira obra editada sobre esse composto químico foi a coletânea VELOSO, José Mariano da Conceição (Ed.). Alographia dos Alkalis Fixos Vegetal ou Potassa Mineral ou Soda e dos seus Nitratos, segundo as melhores Memorias Estrangeiras que se tem escripto a este assumpto. Lisboa: Officina de Simão Thaddeo Ferreira, 1798.

${ }^{46}$ BROWN, Jeremiah. Extracto do modo de se fazer o salitre nas fabricas de tabaco da Virginia. Lisboa: Off. Joáo António da Silva, 1797.

${ }^{47}$ D'URTUBIE, Theodoro. Memoria, ou extracto sobre o Salitre: trasladada do manual do artilheiro de Theodoro D'Urtubie. Lisboa: Regia Officina Typografica, 1797.
} 
D. Rodrigo e frei Mariano: A política portuguesa de produçấo de salitre na virada DO SÉCULO XVIII PARA O XIX

Magnus Roberto de Mello Pereira

sobre a prática de se fazer salitre. É possível que o autor desta última seja o próprio Veloso e a obra, o relato de suas experiências químicas no Arco do Cego. A impressão deste opúsculo, ao qual ainda não foi possível ter acesso, pode ser comprovada através das listas de remessas de livros do Arco do Cego às diversas capitanias do Brasil e da África. ${ }^{48}$ Ele aparece também em alguns catálogos da época. No entanto, deve ter tido baixa tiragem, ao contrário de outras obras, e mal fora publicado já estava praticamente esgotado. Num levantamento do estoque do Arco do Cego aparece anotado: "Memória sobre a prática de se fazer salitre há unicamente no armário de cima 75 Exemplares." No ano seguinte, foi ainda traduzida e publicada uma memória sobre o tema de autoria do famoso químico francês Chaptal. ${ }^{49}$ Todos esses manuais foram amplamente distribuídos nas colônias do Brasil e da África, quer para a venda a um suposto público interessado, quer para instruir as pessoas que, por ordem do ministro, foram moblizadas para a busca de jazidas naturais e fabricação de salitre artificial. O envolvimento de Veloso com o projeto de produção do salitre não parou em sua vertente editorial. Ele acabou sendo uma peça importante na constituição da rede criada por d. Rodrigo, uma vez que assumiu a instruçáo de diversos naturalistas comissionados pela coroa, entre eles: Manuel Arruda da Câmara, João Manso Pereira e Hipólito da Costa Pereira. ${ }^{50}$ Além disso, junto com Nogueira da Gama, Carlos Napion e outros assessores próximos ao ministro, frei Veloso era chamado a fazer experiências e testes com salitre, fibras e outros insumos enviados das colônias.

Hão de ambos [ofícios ao Governador do Pará] remeter-se à Junta da Marinha para sua inteligência, e ordenar-se-lhes que os dois Caixôes que trazem esses Ramos de Árvores próprios para darem fio com que se possa fazer Papel os possa guardar no Arsenal no Armazém da Madeira com essa declaraçáo, e faça remetter parte dos mesmos Ramos de cada espécie que trouxer para o padre Frei José Veloso Mariano, a fim que ele faça algumas experiências ao mesmo respeito. ${ }^{51}$

Como se percebe, a forma característica de agir de d. Rodrigo não se ateve à produção de salitre. A sequência básica de edição, experimentação, mobilização de equipes em Portugal e nas colônias para desenvolver a produçáo agrícola, de insumos ou produtos químicos foi padrão. Tal modus operandi pode ser observado também em relação à potassa, às fibras para

\footnotetext{
${ }^{48}$ Ver GAMA, José Saldanha da. Biographia e apreciação dos trabalhos do botânico brasileiro Frei José Marianno da Conceição Velloso. Rio de Janeiro: Typ. Pinheiro, 1869. p. 15-16.

${ }^{49}$ CHAPTAL, Jean Antoine. Extracto acerca do methodo de se fazer nitrato de potassa ou salitre: copiado dos elementos de chymica compostos em francez por J. A. Chaptal; traduzido e impresso por ordem de sua magestade. Lisboa: Offic. de João Procopio Correa da Silva, 1798.

${ }^{50}$ Sobre a correspondência com Manuel Arruda da Câmara, ver SILVA, Maria Beatriz Nizza da. O botânico Fr. José Mariano da Conceição Veloso e sua expedição na Capitania do Rio de Janeiro. Anais. Série História, v. 7-8, 2000-2001. p. 214. Uma carta de Câmara a Veloso foi publicada no Clarim de Pallas, v. 1, maio 1796. ${ }^{51}$ AHU, Reino, 158A.
} 
D. Rodrigo e frei Mariano: A política portuguesa de produçấo de salitre na virada DO SÉCULO XVIII PARA O XIX

Magnus Roberto de Mello Pereira

cordas, à quina, à cochonilha, à batata etc. Assim, as obras editadas no Arco do Cego, e as que precederam a instalação da casa editorial, são um excelente indicador da agenda de prioridades de Souza Coutinho. Basta lembrar que, em sua fase final, logo antes de deixar a pasta do Ultramar e assumir o Real Erário, na Oficina Calcográfica já estavam sendo impressas obras sobre moeda e outros temas relativos a teorias econômicas.

$\mathrm{Na}$ carta em que faz um balanço de sua gestão na pasta do Ultramar, dirigida ao visconde de Anadia, seu sucessor, d. Rodrigo não dava mostras de saber dos desdobramentos que sua transferência para o Real Erário acarretariam. Falava, inclusive, que caberia ao novo ministro a ampliação das nitreiras e da Casa Editorial do Arco do Cego.

Não toco a V. Exa sobre o novo Hospital da Marinha, cômodo, muito convenientemente construído, e que se acha muito adiantado; nas Nitreiras Artificiais, que prometem grande aumento para o futuro, nos Pinhais Reais já hoje de consideravel Rendimento, e que para o futuro prometem muito, dando já agora grande quantidade de Alcatrão; e na Impresão do Arco do Cego, que em táo pouco tempo não só tem produzido muitas Obras, que tem alumiado, e estendido as Culturas, mas que até nos segura a Fundição, e Abrição de Caracteres, de que possam prover-se as Tipografias do Reino; porque V. Exa sucessivamente irá vendo os mesmos objetos, e dando-lhes a conveniente extensão

Deus guarde a V. Exa , Arroios, Arroios, 14 de Junho de $1801 .^{52}$

$\mathrm{O}$ visconde de Anadia não teve tempo, no entanto, de dar atenção à maior parte desses objetos. Numa espécie de golpe branco, Souza Coutinho levou consigo, para o Erário, a equipe e as instituiçôes que caracterizavam a sua política científica. D. João Rodrigues de Sá e Melo herdou um ministério esvaziado de muitas de suas atribuiçóes. Perdeu, inclusive, o comando do complexo da Ajuda. Através de uma portaria de 24 de novembro de 1801, d. Rodrigo foi nomeado Inspetor dos "Reais Estabelecimentos" (Jardim Botânico, Museu, Casa do Risco e Laboratório Químico da Ajuda), que, assim, continuaram sob sua direçáo direta. ${ }^{53}$ A supervisáo dos Pinhais Reais, por sua vez, passou para a Casa da Moeda, que era subordinada ao Erário. De certa forma, ele também levou consigo a Casa Editorial do Arco do Cego. No entanto, como não mais ocupava um ministério de recorte colonial, já não fazia sentido que as instituiçôes sobre as quais tinha ascendência ficassem presas ao antigo recorte. Ao assumir uma pasta ministerial de âmbito nacional e imperial, ele simplesmente integrou, ou foi obrigado a integrar, os preciosos equipamentos de calcografia à Impressão Régia, que também passou a produzir obras com perfil semelhante às anteriormente publicadas no Arco do Cego. Desde então, as correspondências de cunho científico e as remessas

\footnotetext{
52 FUNCHAL, Marquês de. O conde de Linhares. Dom Rodrigo Domingos Antonio de Sousa Coutinho. Lisboa: Typ. Bayard, 1908. p. 201.

${ }^{53}$ AHMCUL, cód. 1863.
} 
D. Rodrigo e frei Mariano: A política portuguesa de produçāo de SAlitre Na Virada DO SÉCULO XVIII PARA O XIX

Magnus Roberto de Mello Pereira

de produtos da natureza enviados das colônias passaram a ser dirigidas ao Erário Régio. Quando iam para a Secretaria do Ultramar, o visconde de Anadia as reencaminhava para lá.

D. Rodrigo não deixou ao desabrigo os seus auxiliares mais diretos. Feijó já tinha sido mandado para o Ceará, com a missão de criar nitreiras naturais na capitania. Nogueira da Gama esteve para ser mandado para Minas, mas foi mantido sob as asas de d. Rodrigo. Entre outras prebendas, ganhou uma patente militar, o cargo perpétuo de secretário do Governo de Minas Gerais e foi nomeado ajudante do Laboratório de Docimástica. Esse laboratório foi criado na Casa da Moeda para integrar José Bonifácio de Andrada e Silva, que retornara a Portugal em 1800, aos projetos de Souza Coutinho. ${ }^{54}$ Mariano da Conceição Veloso foi recompensado com uma pensão de 500\$000. Junto com Hipólito da Costa Perreira, passou a integrar a Junta Literária da Impressáo Régia, responsável por decidir "as obras que devem imprimir-se". ${ }^{55}$ Além disso, o frei continuou a funcionar como um intermediário entre o ministro e a rede de naturalistas espalhada por diversas capitanias do Brasil.

\section{O salitre}

Como dito anteriormente, as políticas de d. Rodrigo não foram exatamente "coloniais". 56 Suas atividades referentes à produção de salitre tiveram início assim que assumiu a pasta do Ultramar. Afora as experiências em pequena escala conduzidas por Feijó e Veloso, o ministro promoveu em Lisboa uma tentativa relativamente bem-sucedida de produção de salitre em maior escala. Manoel Jacinto Nogueira da Gama foi responsável por ela e deixou um extenso relato sobre essa vertente reinol da proposta de Souza Coutinho. Em 1803, o matemático e naturalista mineiro publicou, pela Impressão Régia, um pequeno livro em que relata seu envolvimento pessoal no processo. A obra foi fruto de uma apresentaçáo pública, feita no ano anterior, na Sociedade Real Marítima, Militar e Geográfica. Essa instituição foi criada por Souza Coutinho, tendo entre suas figuras-chave Marino Miguel Franzini e José Bonifácio de Andrade e Silva. O livro de Nogueira da Gama passou em branco para a maior parte da historiografia brasileira sobre o tema devido a uma peculiaridade: o opúsculo não trata do Brasil, mas de Portugal. Muitas informaçóes pertinentes foram deixadas de lado devido a esse recorte nacional anacrônico frequentemente adotado pelos historiadores brasileiros.

\footnotetext{
${ }^{54}$ Sobre esse laboratório e seu funcionamento precário, ver VARELA, Alex Gonçalves, 2006, op. cit., p. 159-170.

${ }^{55}$ Decreto de Instituição da Nova Junta, de 20 de dezembro de 1801.

${ }^{56}$ Considere-se, de passagem, que esse termo, que utilizamos por convenção e comodismo, atualmente provoca mais confusáo do que traz benefício à historiografia. Diria que a palavra colonial, tal como costuma ser utilizada na historiografia, é o artifício intelectual e linguístico criado pelas elites brasileiras do período pós-independência para escamotear o seu papel colonizador. Colonial é a palavra na qual está escondida a operação utilizada pelos integrantes dessa elite para transitarem da condição de colonizadores para a de colonizados.
} 
D. Rodrigo e frei Mariano: A política portuguesa de produção de salitre na virada DO SÉCULO XVIII PARA O XIX

Magnus Roberto de Mello Pereira

Segundo Nogueira da Gama, um negociante lisboeta e o francês Luiz Thomaz Regnault iniciaram, em 1798, uma experiência de produção artificial de salitre no Braço de Prata, no bairro lisboeta do Poço do Bispo. D. Rodrigo encarregou-o de conhecer o empreendimento. Quando Regnault mostrou-lhe as primeiras amostras do salitre ali produzido, Gama exultou de contentamento patriótico: "Conduziu-me às casas de sua residência; e mostrou-me dois, ou tres alguidares com algum salitre, que disse já ter obtido. Não sei expressar o transporte de alegria, que sentiu a minha alma com a vista do salitre, não porque reputasse misteriosa a sua formaçáo; náo porque desconfiasse do bom êxito das nitreiras artificiais; mas por ser o primeiro, que se dizia fora delas obtido em Portugal". ${ }^{57}$

O comerciante teria tentado obter do ministro o monopólio da produção de salitre e potassa em Portugal, além das rendas da limpeza das ruas de Lisboa e um empréstimo de 250 ou 300 mil cruzados. As condiçôes não foram aceitas, mas chegou-se a um acordo para a compra do negócio, que foi estatizado por $997 \$ 950$ réis, em 14 de agosto de 1798. Nogueira da Gama foi nomeado supervisor e Regnault, contratado como mestre produtor, com a incumbência de transmitir os seus conhecimentos. Mais tarde, o francês foi despedido, por se demonstrar pouco propenso a repassar os seus saberes, e o luso-brasileiro acabou assumindo o controle total da nitreira. Apesar de uma série de problemas, o empreendimento pode ser considerado bem-sucedido e forneceu salitre por anos ao complexo militar português. Além disso, muitas das amostras de salitre enviadas das colônias eram mandadas para o Braço de Prata, para serem analisadas por Nogueira da Gama. Segundo seus biógrafos, ele era amigo pessoal de Souza Coutinho, com quem "teve a maior particularidade até a última hora", 58 tornando-se um dos seus braços direitos. ${ }^{59}$ Em retribuição, como vimos, foi fartamente recompensado com patentes e cargos públicos. D. Rodrigo costumava ir pessoalmente à nitreira comandada por Nogueira da Gama, para acompanhar o sucesso do empreendimento. ${ }^{60}$ O intelectual mineiro parece ter sido, também, um dos responsáveis por convidar outros luso-brasileiros que vieram trabalhar no Arco do Cego. José Feliciano Fernandes Pinheiro, o futuro visconde de Sáo Leopoldo, conta em suas memórias como fora aliciado para o grupo.

Encontrando-me um dia com Antônio Carlos, meu patrício e amigo, que igualmente vivia desempregado, referiu-me que Manoel Jacinto Nogueira da Gama o convidara a entrar de colaborador em um estabelecimento literário e tipográfico, que se ia fundar, junto a Arronches

\footnotetext{
${ }^{57}$ GAMA, Manuel Jacinto Nogueira, op. cit. p. 31.

${ }^{58}$ Ver Jornal de Coimbra, n. 55, parte 2, p. 4, 1817; ROCHA, Justiano José da. Biografia de Manoel Jacinto Nogueira da Gama, marquês de Baependi. Rio de Janeiro: Tip. Universal de Laemmert, 1851.

${ }^{59}$ Segundo o historiador José Luís Cardoso "Manuel Jacinto Nogueira da Gama não era apenas um homem da estima técnica e política de d. Rodrigo de Sousa Coutinho. Fazia parte da sua rede próxima no plano profissional mas era também pessoa da confiança íntima e frequentador assíduo da casa da família Linhares no Rio de Janeiro." CARDOSO, José Luiz. Novos elementos para a história do Banco do Brasil (1808-1829): crónica de um fracasso anunciado. Revista Brasileira de História, v. 30, n. 59, p. 181, 2010.

${ }^{60}$ AHU, Reino, maço 158.
} 
D. Rodrigo e frei Mariano: A política portuguesa de produçāo de SAlitre Na Virada DO SÉCULO XVIII PARA O XIX

Magnus Roberto de Mello Pereira

[Arroios], em a quinta do Manique, no sítio denominado do Arco do Cego. A direção do estabelecimento criado sob as vistas imediatas e proteção do ministro do ultramar D. Rodrigo de Souza Coutinho era confiada ao padre mestre frei José Mariano da Conceição Veloso, natural de Minas Gerais, religioso capucho do Rio de Janeiro. Este instruído naturalista estava, como pensionista do Estado, incumbido de procurar companheiros, que o coadjuvassem naquela empresa literária. As vantagens oferecidas eram aposentamento no edifício compreendendo as despesas de mesa, e sobretudo o conhecimento de nossas habilitaçóes pelo governo: tínhamos por obrigação fazer a tradução das obras que nos designassem, principalmente das línguas francesa e inglesa, nas quais éramos bastante versados..

O convite de Antônio Carlos, para mim que nada tinha, era de aceitar-se sem hesitação; e assim o fiz.

Entrei, pois, para o estabelecimento do Arco do Cego, mudando-me para a dita quinta do manique em o 1o de Agosto de 1799; e aí me empreguei na tradução e publicação de obras literárias até 20 de junho de 1801, em que deixei o serviço. ${ }^{61}$

$\mathrm{Na}$ mesma época em que isso acontecia em Portugal, uma série de cartas régias estavam sendo expedidas, com o intuito de deflagrar a produção de salitre nas colônias brasileiras. Em Minas Gerais, as experiências foram confiadas pelo governador Bernardo José de Lorena a outro padre naturalista: Joaquim Veloso de Miranda. Por diversas vezes foram enviadas a Portugal amostras do salitre produzido na nitreira de Mau Cabelo, que passou a atender pelo pretensioso nome de Nitreiras e Fábrica de Pólvora da Capitania das Minas. ${ }^{62}$ Posteriormente, o mineralogista José Vieira Couto foi encarregado da prospecção de jazidas de terra ricas em nitratos em Minas Gerais. ${ }^{63}$ Como resultado de seus estudos, deixou uma série de relatos. ${ }^{64}$

Em São Paulo, foram contratados os naturalistas João Manso Pereira, professor régio no Rio de Janeiro, e Francisco Vieira Goulart, formado na Universidade de Coimbra, para a busca de terrenos salitrosos na capitania. ${ }^{65}$ Os primeiros resultados mais positivos apareceram em 1798. Goulart descobrira vestígios promissores de salitre em Morro Branco e Manso, na vila de Castro. ${ }^{66}$ Em 1799 , Manso deu início à construção de uma nitreira artificial na

\footnotetext{
${ }^{61}$ PINHEIRO, José Feliciano Fernandes. Memórias. Revista do Instituto Histórico Geográfico Brasileiro, Rio de Janeiro, v. 49, parte 2, p. 15, 1874.

${ }^{62}$ Ver Revista do Arquivo Público Mineiro, Belo Horizonte, v. 3, p. 273-274, 1898; AHU, Minas Gerais, Cx. 144, D03; AHU, Minas Gerais, Cx. 147, D10.

${ }^{63}$ A trajetória do naturalista mineiro pode ser acompanhada em SILVA, Clarete Paranhos da. $O$ desvendar do grande livro da natureza: Um estudo da obra do mineralogista José Vieira Couto, 1798-1805. São Paulo: Annablume, 2002.

${ }^{64}$ Ver, em especial, COUTO, José Vieira. Memória sobre as nitreiras naturais e artificiais de Monte Rorigo na Capitania de Minas Gerais. 1803. AHU, Cód. 2095.

${ }^{65} \mathrm{O}$ processo já foi descrito, nas suas linhas mestras, em VARELA, Alex Gonçalves. Atividades cientificas na "Bela e Bárbara" capitania de São Paulo (1796-1823). São Paulo: Annablume, 2009. p. 128-140.

${ }^{66}$ GOULART, Francisco Vieira. Sobre as nitreiras na Capitania de São Paulo. Documentos Interessantes para a História e Cultura de São Paulo, São Paulo, v. 31, p. 182-188, 1901. Ver também Documentos Interessantes para a História e Cultura de São Paulo, São Paulo, v. 29, p. 65-6, 1899.
} 
D. Rodrigo e frei Mariano: A política portuguesa de produçấo de salitre na virada DO SÉCULO XVIII PARA O XIX

Magnus Roberto de Mello Pereira

vila de Santos. A iniciativa foi acompanhada de perto pelo ministro e pelo governador, que procurou angariar o máximo apoio ao projeto. ${ }^{67}$ É interessante perceber que Veloso tinha, inclusive, o papel de instruir a correspondência do ministro. "Recebi a Carta de Vossa Paternidade me dirigio à qual vou responder na maneira seguinte. Que sua Alteza Real encarrega a Vossa Paternidade de louvar muito os esforços do Autor do Aligeiramento da fermentação do salitre com as sementes de Algodão". ${ }^{68} \mathrm{Na}$ sequência, a carta trata de diversos assuntos referentes à atuação do naturalista e outros assuntos pertinentes às políticas fomentistas do ministro.

O propósito de João Manso era produzir salitre a partir de uma mistura de urina e cal. A escolha de Santos foi tributada ao fato de a vila contar com uma grande população permanente, só comparável à capital e a Paranaguá, o que facilitaria a recolha da urina para o experimento. A nitreira artificial de Manso deu origem a uma pequena publicação feita com base numa carta do naturalista, que foi transformada numa publicação do Arco do Cego e distribuída por Portugal e suas colônias. ${ }^{69}$ Este foi um dos casos em que a mera publicação da tradução de obras estrangeiras sobre um tema foi ultrapassada. A impressão do opúsculo de João Manso representa um proceso de internalização e nacionalizaçáo tecnológica, um conhecimento acumulado em campo que foi difundido na grande rede envolvida no projeto da autossuficiência em salitre.

$\mathrm{Na}$ Bahia, o governador também atendeu às ordens de d. Rodrigo e encarregou José de Sá Bittencourt Accioli de fazer uma tentativa de retomar a exploração de salitre na serra de Montes Altos. Décadas antes, ali ocorrera uma longa experiência de produção de salitre, que encerrou no meio de múltiplos conflitos. O mineiro Accioli, suspeito de inconfidente, vivia uma espécie de exílio branco na Bahia. Agarrou-se a essa oportunidade de se redimir ante a coroa. Fez tentativas de estabelecer colonos na regiáo com vistas a retomar a produçáo de salitre e reabrir a estrada até o litoral, buscando viabilizar o escoamento da produção, dessas experiências resultaram algumas memórias: Sobre os meios de realizar a extração do salitre dos Montes Altos e Memória sobre a viagem do terreno nitroso. ${ }^{70}$

Nas capitanias do Nordeste, Souza Coutinho comissionou o médico e naturalista Manuel Arruda Câmara para que ele itinerasse pelo sertão nordestino, de Pernambuco ao Ceará, entre 1797 e $1799 .{ }^{71}$ As instruçóes que Câmara recebera insistiam em que ele investigasse principalmente as ocorrências de salitre. Logo a seguir, foi enviado ao Ceará o naturalista

\footnotetext{
${ }^{67}$ Documentos Interessantes para a História e Cultura de São Paulo, São Paulo, v. 87, p. 168-177, 1963.

${ }^{68}$ BORGMEIER, Tomaz, op. cit., p. 22.

${ }^{69}$ PEREIRA, João Manso. Copia de huma carta sobre a nitreira artificial estabelecida na villa de Santos de capitania de S. Paulo. Lisboa: Offic. da Casa Litteraria do Arco do Cego, 1800.

${ }^{70}$ AHU, Bahia, Cx. 213, D15016.

${ }^{71}$ Ver MELLO, José Antonio Gonsalves de (Ed.). Estudo biográfico. In: Manuel Arruda da Câmara: Obras reunidas. Recife: Fundação Cultural Cidade do Recife, 1982. p. 25-35; KURY, Lorelai. Manuel Arruda da Câmara: a República das Letras nos sertôes. In: (Org.). Sertóes adentro: Viagens nas caatingas. Séculos XVI a XIX. Rio de Janeiro: Andrea Jakobsson Estúdio, 2012. p. 162-202.
} 
D. Rodrigo e frei Mariano: A política portuguesa de produção de salitre na virada DO SÉCULO XVIII PARA O XIX

Magnus Roberto de Mello Pereira

João da Silva Feijó, parceiro de Veloso nos experimentos iniciais feitos em Lisboa. Feijó iniciou as suas tentativas de produção de salitre em Tatajuba, na serra dos Cocos, local onde Arruda Câmara encerrara a sua expedição, em meados de $1799 .^{72}$ Em sua curta estadia em Pernambuco, Feijó examinou amostras de salitre vindas da serra dos Cocos, em poder do bispo Azeredo Coutinho, que, à época, transformara o seminário de Olinda em um centro de difusão de saberes iluministas. ${ }^{73}$ Como $\mathrm{d}$. Rodrigo acenava com recompensas a quem encontrasse o composto químico, era comum que fossem enviadas a Lisboa notícias sobre a existência de jazidas no sertão nordestino. Após instalar-se na capitania do Ceará, Feijó dedicou-se a verificar essas notícias sobre a existência de depósitos de salitre natural. Entre os diversos locais examinados, o único que pareceu promissor ao naturalista foi o de uma jazida situada em Tatajuba. Iniciada a produção experimental de salitre, Feijó enviou uma primeira partida a Lisboa, a qual daria início a uma série de controvérsias referentes ao preço e à qualidade do composto produzido no Ceará. Amostras do salitre elaborado por Feijó foram analisadas em Lisboa por Carlo Antonio Napione, um químico de origem italiana trazido para Portugal por d. Rodrigo, que assumira a direção das Reais Fábricas da Pólvora, em setembro de 1801. Nogueira da Gama também recebeu para análise amostras do salitre produzido em Tatajuba. Criou-se entáo todo um debate sobre a qualidade e preço do composto preparado no Ceará. A experiência acabou abortada devido à queda de d. Rodrigo, em 1801.

Feijó, no entanto, não foi o único herdeiro de Arruda Câmara na missão de procurar salitre no sertão nordestino. Exatamente na mesma época em que ele começava a esquadrinhar o Ceará, o mesmo era feito no Maranhão e no Piauí pelo padre Joaquim José Pereira e pelo bacharel Vicente Jorge Dias Cabral. ${ }^{74} \mathrm{O}$ padre Pereira havia descoberto terras salitrosas na região de Valença e acabou sendo chamado a Portugal. ${ }^{75}$ Fez um estágio no Braço de Prata sob a supervisão de Nogueira da Gama e, a seguir, recebeu de d. Rodrigo ordens para retornar ao Brasil e percorrer os sertôes do Maranhão e do Piauí. Antes da viagem de retorno, o ministro levou-o para "ajoelhar ao Trono, e beijar a mão" de d. João. Nestes pequenos detalhes percebe-se, mais uma vez, o esforço feito por Souza Coutinho para colocar o príncipe na condição de coautor de suas políticas.

Pereira e Dias Cabral percorreram as capitanias do Piauí e do Maranhão entre os anos de 1799 e 1803, com o objetivo de fazer um amplo levantamento do meio natural e das potencialidades econômicas do sertão. Todavia, o padre Pereira recebera instruçôes expres-

\footnotetext{
${ }^{72}$ PEREIRA, Magnus Roberto de Mello. João da Silva [Feijó?]: A trajetória de um homem de ciências lusobrasileiro. In: PEREIRA, Magnus R. M.; SANTOS, Rosângela M. F. (Eds.). João da Silva Feijó: Um homem de ciência no Antigo Regime português. Curitiba: Editora da UFPR, 2012. p. 80.

${ }^{73}$ Ver NOBRE, Geraldo S. João da Silva Feijó: Um naturalista no Ceará. Fortaleza: Grecel, 1978. p. 182; AHU, Ceará, Cx. 13, D749.

${ }^{74}$ Sobre a viagem filosófica dos dois naturalistas, ver BONATO, Tiago. Da investigação mandada fazer por $V$. Ex. ${ }^{a}$ sobre os diferentes produtos da natureza: dois viajantes iluministas pelo sertão da América portuguesa: Monografia (graduação em história) - Universidade Federal do Paraná, Curitiba, 2007.

${ }^{75}$ VASCONCELLOS, José M. P. Selecta Brasiliense. Rio de Janeiro: Laemmert, 1868. p. 264.
} 
sas de fazer do "Salitre natural, ou mineral o primeiro objeto" de suas observações. Assim, ele dedicou ao composto químico um conjunto de memórias, assim como Dias Cabral. ${ }^{76}$ A conclusão da dupla de naturalistas foi de que no sertão nordestino não existiam jazidas economicamente aproveitáveis de salitre natural, mas que existiam condições favoráveis para o estabelecimento de nitreiras artificiais de pequeno porte. $\mathrm{O}$ sacerdote nutria altas pretensôes a respeito. Imaginou ser possível que d. Rodrigo o incumbisse da produçáo artificial de salitre no sertão nordestino. No entanto, Feijó contava com o apoio de Nogueira da Gama e foi sobre esse naturalista que recaiu a escolha, para que, após a fase de prospecção, fosse dado início a experiências de produção em escala econômica.

\section{Para concluir}

Com a queda de Souza Coutinho, e de todo o chamado partido inglês, a política de alcançar a autossuficiência na produção de salitre foi praticamente abandonada. Após a "travessia do deserto", d. Rodrigo reemergiu com força na conjuntura da invasão francesa e da fuga da família real para o Brasil. No Rio de Janeiro, ele repetiu muitas das práticas adotadas em seu primeiro período na administração portuguesa, entre elas a criação de uma casa editorial: a Imprensa Régia. Trouxe Carlos Napion consigo, a quem atribuiu a criação de uma fábrica de pólvora no Rio de Janeiro, o que acarretou a volta da questáo do fornecimento de salitre. ${ }^{77}$ Quando Feijó esteve no Rio de Janeiro, em 1811, chegou a tratar com o ministro a retomada da produção no Ceará. d. Rodrigo deu ordens expressas para que isso ocorresse. No entanto, morreu pouco depois, antes que fosse dado qualquer passo nesta direção. Não se sabe, porém, quais eram as relaçôes entre Souza Coutinho e Conceição Veloso, neste período. $^{78}$

Ao contrário do que imaginara inicialmente, nunca foram encontradas jazidas naturais de maior porte no sertáo nordestino. Isto já era claro para João da Silva Feijó e para Vicente Jorge Dias Cabral. Além disso, ambos concordavam que não seria economicamente viável que a coroa se envolvesse diretamente na criação de salitreiras artificiais, como fizera no Braço de Prata, em Portugal. As condiçóes das colônias eram outras e não havia a menor condição de concorrer com o preço do salitre produzido na Índia e na América do Norte. "Se se (...) fizer a despesa por conta da fazenda Real, o preço módico por que vem o Nitro de Bengala, e do Norte fará parecer extraordinárias as despesas necessárias para se estabelecer o fabrico do Salitre". ${ }^{79}$

\footnotetext{
${ }^{76}$ AHU, Maranhão, Cx. 127, D9555.

77 Ver MASCARENHAS, José Manuel. Portuguese Overseas Gunpowder Factories. In: BUCHANAN, Brenda J. (Org.). Gunpowder, Explosives and the State. Londres: Ashgate, 2006. p. 183-205.

${ }^{78}$ Frei Veloso morreu em julho de 1811 e d. Rodrigo, em janeiro de 1812, ambos no Rio de Janeiro.

${ }^{79}$ AHU, Maranhão, Cx. 127, D9555.
} 
D. Rodrigo e frei Mariano: A política portuguesa de produçấo de salitre na virada DO SÉCULO XVIII PARA O XIX

Magnus Roberto de Mello Pereira

Feijó não tinha interesse em que sua função de naturalista da coroa se transformasse na de gerente de uma unidade de produçáo de salitre. Afirmava que "a mim, como naturalista, só me toca apontar o lugar e os meios de o extrair comodamente e pô-lo em ponto de servir" ${ }^{80}$ Ele e seu desafeto no Ceará, o escrivão da Fazenda Francisco Bento Maria Targini, concordavam que os métodos utilizados náo levariam ao barateamento do salitre. $\mathrm{O}$ modelo ideal de produçáo proposto pelos dois era aquele utilizado nos engenhos de cana movidos a máo de obra escrava africana, uma vez que os índios, contratados como trabalhadores livres, eram acusados de dar prejuízo devido à sua "inata preguiça".

enquanto estas Oficinas forem Sujeitas a tais despesas, e nelas se não introduzisses escravos próprios, e melhores, e mais como dos utensílios, não poderiam fazer conta a Sua Alteza Real, e é o que convence a diária experiência, quando não fosse bastante as que nos dá a conduta e economia dos Engenhos d'Açúcar, que se não forem trabalhados com escravatura, não faria conta alguma aos proprietários; donde parece seria vantajoso a Sua Alteza Real o ter nestas oficinas Escravos, Carros, Carretas, e Bois próprios proporcionalmente ao seu maneio manejo; este corte de despesas diárias não deixaria de concorrer, com muita vantagem para o cômodo preço do salitre.

A questão da mão de obra também era central nas análises de Dias Cabral. Para ele, seria ilusório imaginar que a atividade atraísse os sertanejos. "Em uma palavra só o trabalho a cavalo em perseguição dos gados fazem de boa vontade não sendo aturado por muito tempo outro qualquer trabalho, dizem eles é próprio dos escravos cativos. Tal é o prejuízo da educação destes povos. E que lucro se tirará então sendo as Nitreiras deixadas a descrição do povo? Eu julgo que nenhum tentará este estabelecimento". No entanto, o bacharel-naturalista imaginava que os índios poderiam ser levados a produzir salitre.

Não acho com tudo que se deva desprezar inteiramente uma produção própria do País, mas sim tentar-se um pequeno estabelecimento naqueles dos lugares com Índios aos quais se pague mais alguma coisa, do que manda o regimento por eles mesmos fazer-se plantar a terra por método regular lavrando-a, estrumando-a: o administrador poderá purificar também o Sal de Glauber ou Sulfato de potassa, de que tanto abunda o Sertão, e com preferência na fazenda da Sabambaia que é riquíssima dele, mais ainda, que a vargem do Salitre do Iguará. ${ }^{81}$

Outras eram as expectativas do padre Joaquim José Pereira. Ele imaginava que deveria ser utilizado o contingente militar para a produção do composto. Advertia, porém, para que a produçâo fosse em pequena escala. Os salitreiros deveriam "primeiramente serem pequenos, e multiplicados como de um só telheiro" e dispersos pelo sertấo. ${ }^{82}$

\footnotetext{
${ }^{80}$ AHCMP, Laboratório de Química, maço 718.

${ }^{81}$ AHU, Maranhão, Cx. 127, D9555.

${ }^{82}$ AHU, Maranhão, Cx. 127, D9555. 
D. Rodrigo e frei Mariano: A política portuguesa de produção de salitre na Virada DO SÉCULO XVIII PARA O XIX

Magnus Roberto de Mello Pereira

A capitania de Minas foi a única em que a exploração de pequenas jazidas, criadas em decorrência das antigas políticas, teve alguma expressão. Elas chegaram a abastecer a Fábrica de Pólvora de Vila Rica e a da lagoa Rodrigo de Freitas, no Rio de Janeiro. Em 1809, d. Rodrigo fez publicar pela Imprensa Régia do Rio de Janeiro o texto em que Vieira Couto relatava as suas observaçóes e propostas resultantes de suas viagens ao Monte Rorigo. ${ }^{83}$ Mais uma vez, observa-se a difusão de ganhos tecnológicos obtidos no terreno, com o suporte financeiro da coroa, através da edição de um livro. Este trabalho foi um primeiro passo na aceitação de que nas colônias as condiçôes socioeconômicas eram diferentes, o que requeria soluçôes específicas. Couto buscou conciliar a exploração de jazidas naturais com a criação de salitreiras artificiais. Uma de suas preocupaçôes era preservar as ocorrências naturais, impedindo o uso predatório das mesmas.

Em 1813, o barão de Eschwege, enviado pela coroa a Minas, observou que "Como não se poderá fazer naqueles Sertóes incultos Salitreiras artificiais, assim como indica a arte, será um grande Remédio, ao menos de conservar as Salitreiras naturais" ${ }^{84}$ Pautando-se nas observaçôes de Vieira Couto, Eschwege sugeriu uma série de medidas destinadas à preservação das jazidas, que costumavam ser exploradas até a exaustão. As sugestôes de ambos foram, aparentemente, inúteis.

Já estava claro, à época, que a política de preços adotados pela coroa teria um papel determinante, mas, no entanto, os resultados nem sempre eram os que o estudo da nascente Economia Política sugeria. Se os preços eram baixos, havia desestímulo à produção, em especial a das salitreiras artificiais, dado seu custo mais elevado. Se a coroa concedia melhores preços, ocorria o imediato aumento da exploração predatória de jazidas naturais e não criação de salitreiras artificiais. ${ }^{85}$ Assim, já estava colocada uma série de questóes próprias à economia brasileira do período, as quais vêm sendo debatidas ao longo dos dois últimos séculos.

A intelectualidade luso-brasileira já percebia que estavam presentes certas marcas culturais provocadas pelo uso intensivo de mão de obra escrava, o que gerava uma cisão entre as atividades que eram consideradas próprias de cativos e outras consideradas de homens livres. As formas de trabalho mais intensivo tendiam a ser desqualificadas como apropriadas apenas a escravos. A disparidade entre a imensa extensão territorial e a população relativamente diminuta havia gerado a percepção de que a disponibilidade de recursos naturais era infinita. Os integrantes da rede constituída por $\mathrm{d}$. Rodrigo, ao passarem do conhecimento livresco

\footnotetext{
${ }^{83}$ COUTO, José Vieira. Memória sobre as salitreiras naturaes de Monte Rorigo; Maneira de as auxiliar por meio das artificiaes; Refinaria do Nitrato de Potassa, ou Salitre; Escrita no anno de 1803. Rio de Janeiro: Impressão Régia. 1809. Monte Rodrigo, o nome dado pelo naturalista em homenagem a Souza Coutinho não pegou, como diríamos, e hoje a elevação é conhecida como serra do Cabral.

${ }^{84}$ Ver Revista do Arquivo Público Mineiro, Belo Horizonte, v. 4, p. 310, 1889; e também ESCHWEGE, Wilhelm Ludwig von. Pluto brasiliensis. São Paulo: Cia. Editora Nacional, 1944. v. 2, p. 311-321.

${ }^{85}$ A Revista do Arquivo Público Mineiro publicou, em 1889, todo um conjunto de fontes referentes ao salitre em Minas Gerais, que são excelentes para a discussão dessa questão. Revista do Arquivo Público Mineiro, Belo Horizonte, v. 4, p. 299-316, 1889.
} 
D. Rodrigo e frei Mariano: A política portuguesa de produçấo de salitre na virada DO SÉCULO XVIII PARA O XIX

Magnus Roberto de Mello Pereira

e europeu, proveniente da formaçáo universitária, para o trabalho em campo no Brasil, depararam-se com uma outra realidade. $\mathrm{O}$ desenrolar desse longo e amplo projeto voltado a desenvolver a produção de salitre no mundo português é um exemplo eloquente do processo de ajuste às condiçóes encontradas nas colônias. Quase tudo apontava para o uso extensivo e predatório dos recursos naturais. E assim foi!

\section{Siglas}

AHCMP - Arquivo Histórico da Casa da Moeda de Portugal

AHMCUL - Arquivo Histórico do Museu de Ciências da Universidade de Lisboa

AHU - Arquivo Histórico Ultramarino

ANRJ - Arquivo Nacional do Rio de Janeiro

BNL - Biblioteca Nacional de Lisboa

\section{Referências bibliográficas}

BONATO, Tiago. Da investigação mandada fazer por $V$. Ex.a sobre os diferentes produtos da natureza: dois viajantes iluministas pelo sertão da América portuguesa: Monografia (graduação em História) - Universidade Federal do Paraná, Curitiba, 2007.

BORGMEIER, Tomaz, O.F.M. Flora Fuminensis de Frei José Mariano da Conceição Vellozo. Documentos. Rio de Janeiro: Arquivo Nacional, 1961.

BOSCHI, Caio. Política e edição: os naturais de Brasil nas reformistas oficinas do Arco do Cego. In: DUTRA, Eliana; R. MOLLIER, Jean-Yves. (Org.). Política, nação e ediçãa: o lugar dos impressos na construção da vida política: Brasil, Europa e Américas nos séculos XVIII-XX. São Paulo: Annablume, 2006.

BRAGANÇA, Aníbal. Arco do Cego e Impressão Régia (Lisboa e Rio de Janeiro): sobre rupturas e continuidades na implantação da imprensa no Brasil. In: XXXI CONGRESSO BRASILEIRO DE CIÊNCIAS DA COMUNICAÇÃO, Natal, 2008.

BROWN, Jeremiah. Extracto do modo de se fazer o salitre nas fabricas de tabaco da Virginia. Lisboa: Off. João António da Silva, 1797.

CARDOSO, José Luiz. Novos elementos para a história do Banco do Brasil (1808-1829): crónica de um fracasso anunciado. Revista Brasileira de História, v. 30, n. 59, p. 181, 2010. CHAPTAL, Jean Antoine. Extracto acerca do methodo de se fazer nitrato de potassa ou salitre: copiado dos elementos de chymica compostos em francez por J. A. Chaptal; traduzido e impresso por ordem de sua magestade. Lisboa: Offic. de João Procopio Correa da Silva, 1798. 
D. Rodrigo e frei Mariano: A política portuguesa de produçấo de SAlitre na Virada DO SÉCULO XVIII PARA O XIX

Magnus Roberto de Mello Pereira

COUTO, José Vieira. Memória sobre as salitreiras naturaes de Monte Rorigo; Maneira de as auxiliar por meio das artificiaes; Refinaria do Nitrato de Potassa, ou Saitre; Escrita no anno de 1803. Rio de Janeiro: Impressão Régia. 1809.

CUNHA, Lygia da F. F. Notícia Histórica. In: Oficina Tipográfica, Calcográfica e Literária do Arco do Cego. Estampas. Rio de Janeiro: Biblioteca Nacional, 1976.

CURTO, Diogo Ramada. D. Rodrigo de Sousa Coutinho e a Casa Literária do Arco do Cego. In: A Casa Literária do Arco do Cego (1799-1801). Lisboa: Imprensa Nacional/Casa da Moeda, 1999.

CURTO, Diogo Ramada; FARIA, Miguel Figueira de (Ed.). Casa Literária do Arco do Cego: exemplo singular na história da ediçáo ilustrada em Portugal. Apontamentos para uma biografia. In: Actas do Colóquio "A Casa Literária do Arco do Cego". Anais. Universidade Autónoma de Lisboa, Série História, v. 7-8, 2000-2001.

D'URTUBIE, Theodoro. Memoria, ou extracto sobre o Salitre: trasladada do manual do artilheiro de Theodoro D'Urtubie. Lisboa: Regia Officina Typografica, 1797.

DENIPOTI, Cláudio; PEREIRA, Magnus Roberto de Mello. Sobre livros e dedicatórias: D. João e a Casa Literária do Arco do Cego (1799-1801). História Unisinos, v. 17, p. 257271, 2013.

DIAS, Maria Odila da Silva. Aspectos da ilustração no Brasil. Revista do Instituto Histórico Geográfico Brasileiro, Rio de Janeiro, v. 278, p. 105-170, 1968.

ESCHWEGE, Wilhelm Ludwig von. Pluto brasiliensis. São Paulo: Cia. Editora Nacional, 1944. v. 2.

FERRAZ, Márcia H. M. A produção do salitre no Brasil colonial. Química Nova, v. 23, p. 845-850, 2000.

FIGUEIRÔA, Sílvia F. de M.; SILVA, Clarete P. da; PATACA, Ermelinda M. Aspectos mineralógicos das "Viagens Filosóficas" pelo território brasileiro na transição do século XVIII para o século XIX. História, Ciências, Saúde: Manguinhos, v. 11, p. 713-729, 2004.

FUNCHAL, Marquês de. O conde de Linhares. Dom Rodrigo Domingos Antonio de Sousa Coutinho. Lisboa: Typ. Bayard, 1908.

GAMA, José Saldanha da. Biographia e apreciação dos trabalhos do botânico brasileiro Frei José Marianno da Conceição Velloso. Rio de Janeiro: Typ. Pinheiro, 1869.

GAMA, Manoel Jacinto Nogueira da. Memoria sobre a absoluta necessidade que ha de Nitreiras nacionaes para a independencia e defensa dos Estados: com a descripção da origem, actual estado, e vantagens da Real Nitreira Artificial de Braço de Prata. Lisboa: Impressão Régia, 1803.

GONÇALVES, Adelto. Bocage: o perfil perdido. Lisboa: Caminho, 2003.

GOULART, Francisco Vieira. Sobre as nitreiras na Capitania de São Paulo. Documentos Interessantes para a História e Cultura de São Paulo, São Paulo, v. 31, p. 182-188, 1901. 
D. Rodrigo e frei Mariano: A política portuguesa de produçấo de salitre na virada DO SÉCULO XVIII PARA O XIX

Magnus Roberto de Mello Pereira

GOUVÊA, Maria de Fátima S. Trajetórias administrativas e redes governativas no Império Português. (1668-1698) In: VIa Jornada Setecentista; Conferências \& Comunicaçóes. Curitiba: Aos Quatro Ventos, 2006. p. 402.

HESPANHA, António Manuel. Para uma teoria da história institucional do antigo regime. In: __ Poder e instituiçôes na Europa do antigo regime. Lisboa: Fundação Calouste Gulbenkian, 1984. p. 68.

KURY, Lorelai. Homens de ciência no Brasil: impérios coloniais e circulação de informaçôes (1780-1810). História, Ciências, Saúde: Manguinhos, v. 11, supl. 1, p. 109-129, 2004.

. Manuel Arruda da Câmara: a República das Letras nos sertôes. In: . (Org.). Sertôes adentro: Viagens nas caatingas. Séculos XVI a XIX. Rio de Janeiro: Andrea Jakobsson Estúdio, 2012. p. 162-202.

LENORMAND, Marie-Anne. Histoire de Jean VI, roi de Portugal: depuis sa naissance jusqu’a sa mort en 1826, avec des particularités sur sa vie privée et sur les principales circonstances de son règne. Paris: Ponthieu et compagnie, 1827.

LOPES, Maria Margaret; SILVA, Clarete Paranhos; FIGUEIRÔA, Sívia F. de M.; PINHEIRO, Rachel. Scientific culture and mineralogical sciences in the Luzo-Brazilian Empire-the work of João da Silva Feijó (1760-1824) in Ceará. Science in Context, v. 18, p. 201-224, 2005. LUNA, Fernando J. Alographia dos álkalis... de Frei Conceiçâo Veloso: um manual de química industrial para produção da potassa no Brasil colonial. Química Nova, v.31, n. 8, pp. 2214-2220, 2008.

- Frei José Mariano da Conceição Veloso e a divulgação de técnicas industriais no Brasil colonial: discussão de alguns conceitos das ciências químicas. História, Ciências, Saúde: Manguinhos, v. 16, p. 145-157, 2009.

MACEDO, Roberto. História administrativa do Brasil. Rio de Janeiro: Dasp, 1964. v. 6.

MASCARENHAS, José Manuel. Portuguese Overseas Gunpowder Factories. In: BUCHANAN, Brenda J. (Org.). Gunpowder, Explosives and the State. Londres: Ashgate, 2006.

MELLO, José Antonio Gonsalves de (Ed.). Estudo biográfico. In: . Manuel Arruda da Câmara: Obras reunidas. Recife: Fundação Cultural Cidade do Recife, 1982.

MOTA, Carlos Guilherme. Atitudes de inovação no Brasil. 1789-1801. Lisboa: Livros Horizonte, 1972.

NOBRE, Geraldo S. João da Silva Feijó: Um naturalista no Ceará. Fortaleza: Grecel, 1978.

NOVAES, Fernando. A Estrutura e dinâmica do antigo sistema colonial (séculos XVI-XVIII). São Paulo: Cebrap, 1974.

NUNES, Maria de Fátima; BRIGOLA, João Carlos. José Mariano da Conceição Veloso (1742-1811), um frade no Universo da Natureza. In: A Casa Literária do Arco do Cego 
D. Rodrigo e frei Mariano: A política portuguesa de produçấo de salitre na virada DO SÉCULO XVIII PARA O XIX

Magnus Roberto de Mello Pereira

(1799-1801). Lisboa: Imprensa Nacional / Casa da Moeda, 1999.

OLIVEIRA LIMA, Manuel de. D. Joâo VI no Brasil. Rio de Janeiro: Typ. do Jornal do Commercio, 1908.

PEREIRA, João Manso. Copia de huma carta sobre a nitreira artificial estabelecida na villa de Santos de capitania de S. Paulo. Lisboa: Offic. da Casa Litteraria do Arco do Cego, 1800. - Rede de mercês e carreira: o "desterro d'Angola" de um militar luso-brasileiro (1782-1789). História: Questóes e Debates, v. 45, p. 111, 2008.

. Um jovem naturalista num ninho de cobras; a trajetória de João da Silva Feijó em Cabo Verde em finais do século XVIII. História: Questóes e Debates, n. 36, p. 29-60, 2002. PEREIRA, João Manso; CRUZ, Ana Lúcia Rocha Barbalho da. Ciência e memória: aspectos da reforma da Universidade de Coimbra de 1772. Revista de História Regional, v. 14, p. 7-48, 2009.

PEREIRA, João Manso; CRUZ, Ana Lúcia Rocha Barbalho da. Ciência, identidade e quotidiano: alguns aspectos da presença de estudantes brasileiros na Universidade de Coimbra, na conjuntura final do período colonial. Revista de História da Sociedade e da Cultura, Coimbra, v. 9, p. 205-228, 2009.

PEREIRA, Magnus Roberto de Mello. João da Silva [Feijó?]: A trajetória de um homem de ciências luso-brasileiro. In: PEREIRA, João Manso; SANTOS, Rosângela M. F. (Ed.). João da Silva Feijó: Um homem de ciência no Antigo Regime português. Curitiba: Editora da UFPR, 2012.

PINHEIRO, José Feliciano Fernandes. Memórias. Revista do Instituto Histórico Geográfico Brasileiro, Rio de Janeiro, v. 49, parte 2, p. 15, 1874.

ROCHA, Justiano José da. Biografia de Manoel Jacinto Nogueira da Gama, marquês de Baependi. Rio de Janeiro: Tip. Universal de Laemmert, 1851.

SILVA, Andrée Mansuy-Diniz. Portrait d'un homme d'État: D. Rodrigo de Souza Coutinho, Comte de Linhares, 1755-1812. Paris: Centre Culturel Calouste Gulbenkian, 2006.

SILVA, Clarete Paranhos da. O desvendar do grande livro da natureza: Um estudo da obra do mineralogista José Vieira Couto, 1798-1805. São Paulo: Annablume, 2002.

SILVA, Maria Beatriz Nizza da. O botânico Fr. José Mariano da Conceição Veloso e sua expedição na Capitania do Rio de Janeiro. Anais. Série História, v. 7-8, 2000-2001. p. 214.

VARELA, Alex Gonçalves. Juro-lhe pela honra de bom vassalo e bom português: análise das memórias científicas de José Bonifácio de Andrada e Silva (1780-1819). São Paulo: Annablume, 2006.

- Atividades cientificas na "Bela e Bárbara" capitania de São Paulo (1796-1823). São Paulo: Annablume, 2009. 


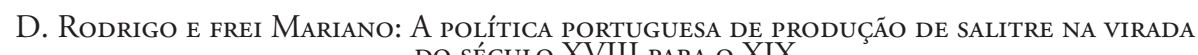
DO SÉCULO XVIII PARA O XIX

Magnus Roberto de Mello Pereira

VASCONCELLOS, José M. P. Selecta Brasiliense. Rio de Janeiro: Laemmert, 1868. p. 264. VELOSO, José Mariano da Conceição. (Ed.). Alographia dos Alkalis Fixos Vegetal ou Potassa Mineral ou Soda e dos seus Nitratos, segundo as melhores Memorias Estrangeiras que se tem escripto a este assumpto. Lisboa: Officina de Simão Thaddeo Ferreira, 1798.

(Ed.). Palladio Portuguez e Clarim de Pallas. Lisboa: Officina Patriarcal, 1796. 2 v. VILLALTA, Luiz Carlos. Impressão em Portugal: da política régia às publicações ilegais. (c. 1750-1806). Disponível em: <http://s3.amazonaws.com/academia.edu.documents/30978426/Villalta_PoliticaEditorialRegiaeImplegalem2011.pdf?AWSAccessKeyId= AKIAIR6FSIMDFXPEERSA\&Expires=1380558714\&Signature=IdivaZ1 bvmmwO5c646 YLGqD6JX0\%3D\&response-content-disposition=inline>. Acesso em: 30 set. 2013.

WEGNER, Robert. Livros do Arco do Cego no Brasil colonial. História, Ciências, Saúde: Manguinhos, v. 11, supl. 1, p. 131-140, 2004.

WEHLING, Arno. O fomentismo português no século XVIII: doutrinas, mecanismos, exemplificaçóes. Revista do Instituto Histórico Geográfico Brasileiro, Rio de Janeiro, v. 316, p. 170-278, 1978. 